\title{
КЛЮЧОВИЙ ДІєВЕЦЬ ІСТОРІї
}

\author{
О.В. Мішалова
}

\begin{abstract}
Анотація. Стаття присвячена огляду основних позицій стосовно проблеми ключового дієвця історії. Можна вирізнити дві позиції: уявлення про аперсоналізованого творця історії та уявлення про персоналізованого дієвця історії. Для першої групи характерно вбачати головного творця історії у певних надприродних сутностях, котру людина не може сприймати безпосередньо за допомогою органів чуття або розумом, однак він або вона здатні спостерігати їхній вплив на хід історії. Наприклад, це може бути: Бог у авраамічних релігійних традиціях (іудаїзм, християнство, іслам); доля та боги у давніх греків і римлян; абсолютний дух у філософії Георга Гегеля. До другої позиції відносяться уявлення про персоналізованого дієвця історії: видатної історичної особистості (політик, правитель, релігійний пророк, герой, харизматичний лідер, пасіонарній, ніцшеанська надлюдина, поет або художник), соціальної групи (соціальний клас, суспільна страта правляча еліта, аристократія, творча меншість, технічна інтелігенція, «нова» інтелігенція постіндустріального суспільства, технократи, соціальні рухи), великих колективних спільнот (народу, нації, раси, етносу, культури та/або цивілізації, культурно-історичні типи, натовпу та мас, людство у цілому). Автор показує, що усі розглянуті позиції єднає спільна думка, що людське минуле є результатом системної діяльності багатьох дієвців історії, однак домінуюча прогресивна роль, як правило, віддається лише одному із них. У статті також вводиться нове поняття «дієвець історії» для позначення видатної історичної особистості (соціальної групи чи великої колективної спільноти), котра своїми діями або бездіяльністю творить історію.
\end{abstract}

Ключові слова: минуле людства, субстантивна філософія історії, дієвець історії, видатна історична особистість, великі колективні спільноти, хід історії.

\section{THE KEY AGENT OF HISTORY}

\begin{abstract}
The paper is devoted to the consideration of the views on the problem of the key agent of history. There are two positions: the concepts of an apersonalized creator of history and the concepts of a personalized agent of history. For the first group it is typical to see the maim creator of history in some supernatural beings, which a person cannot perceive directly with the help of the senses or the mind, but he/she is able to observe their influence on the course of history. For example, it may be God in the Abrahmic religious (Judaism, Christianity, Islam), the fate and gods of the
\end{abstract}


ancient Greeks and Romans, Hegel's Absolute Spirit. The second position includes ideas about the personalized agent of history: an outstanding historical figure (politician, prince, religious prophet, hero, charismatic leader, passionary, Nietzche's superman, poet or artist), a social group (social class, social stratum, ruling elite, aristocracy, creative minority, technical intellectuals, «new» intellectuals of post-industrial society, technocrats, social movements), large collective communities (people, nation, race, ethnos, culture and/or civilization, cultural-historical types, crowds and masses, humanity in general). The author shows that all the considered position are united by the common opinion that the human past is the result of the systemic activity of many historical agents, but the dominant progressive role is usually assigned to only one of them. The paper also introduces a new concept «agent of history» to refer to an outstanding historical figure (social group or large collective community) who, through its actions or inactions, creates history.

Keywords: human past, substantive philosophy of history, agent of history, outstanding historical figure, large collective communities, course of history.

Науки відрізняються одна від іншої тим, що вони встановлюють речі різного роду.

Якого роду речі встановлюе історія? Я відповідаю: res gestae ${ }^{*}$ - дї людей, здійснені у минулому. ${ }^{1}$

Р. Дж. Колінгвуд

У вступі до своєї праці «Ідея історії» Робін Дж. Колінгвуд зазначає, що історія як галузь наукового дослідження характеризується наступними рисами: по-перше, вона наукова, тому що починається з формулювання питань (у той час, як переоповідач легенд починає вже зі знання чогось і розповідає про те, що знає); по-друге, історія гуманістична, оскільки ставить питання про речі, які були вчинені людьми у певні моменти в минулому; по-третє, вона раціональна, тому що обгрунтовує відповіді на свої питання (шляхом звернення до доказів); по-четверте, історія слугує самопізнанню людства, оскільки існує для того, щоб розповісти людині, хто вона є, розповідаючи їй про те, що людина здійснила у минуломуㄹ․ Пізнання людством самого себе через вивчення свого минулого, на думку Колінгвуда, становить основне призначення історії як науки.

Пізнати себе означає знати на що ти здатен; оскільки ніхто не знає, що він може зробити допоки не спробує це зробити, то єдиною підказкою стосовно того, на що людина здатна, є те, що людина вже здійснила. Цінність історії, відповідно, полягає у тому, що вона вчить нас тому, що людина здійснила i, таким чином, що таке людина. ${ }^{3}$

*3 лат. «res gestae» - події, діяння.

${ }^{1}$ Коллингвуд Р.Дж. Идея истории. Автобиография - Москва: Наука, 1980. C. 13. ( : оригінал: Collingwood R.G. The Idea of History. - London : Oxford University Press, 1946. - p. 9.)

2 Див.: там само. - C. 20. (Ibid, p. 18.)

3 Див.: там само. - C. 14. (Ibid, p. 10.) 
Таким чином, людина є «творцем» історії у подвійному сенсі: (1) людина є єдиною дійовою особою історичного процесу, котра своїми діями або бездіяльністю творить історичну дійсність, представлену у сукупності подій минулого; (2) однак, ми дізнаємося про неї завдяки роботі істориків, які, вивчаючи діяльність людей у минулому на основі наявних джерел (археологічних, письмових тощо), створюють історичні наративи (оповіді), націлені на дослідження і встановлення того, що насправді мало місце бути і намагаються дати відповідь на питання, чому відбувалося саме так, а не інакше. У такий спосіб історики створюють історичну реальність, «відкриваючи» минуле для широкого загалу (у даному випадку людина-дієвець виступає у ролі об'єкта дослідження для історика).

3 цією обставиною пов'язана певна складність у використанні звичного нам поняття «суб'єкт історії», оскільки ним можна позначати як людину у минулому (учасника/цю події), так і історика, котрий, оповідаючи про події, фактично робить їх «дійсними» і доступними для загального сприйняття та розуміння. Тому видається доречним запропонувати нове поняття «дієвець історії» для позначення людини (чи групи, спільноти, народу у цілому), яка творить історію безпосередньо своїми рішеннями і діями у минулому. У той же час, відповідно до загальної суб'єктно-об'єктної схеми теорії пізнання (той, хто пізнає - предмет вивчення), під поняттям «суб'єкт історії» ми продовжимо розуміти історика.

Звичайно, у науковій літературі ми можемо зустріти безліч можливих понятійних розмежувань. Наприклад, Ірина Предборська та Світлана Ганаба використовують класичне формулювання «суб'єкт історичного процесу», під яким розуміють носія предметно-практичної діяльності і пізнання, який належить тій або іншій колективній спільноті (група, клас, народ, рух) і у діяльності якого втілюється вектор історичної ходи. Слід віддати належне, автори наголошують, що на сьогодні у науковій літературі не існує ніякого чіткого уявлення про «суб'єкт історії» ${ }^{4}$. Максим Дойчик також користується класичним формулюванням «суб'єкт історичного процесу», зазначаючи, що поняття «суб'єкт» є добре відомим з перших занять з філософії і позначає носія предметно-практичної діяльності та пізнання, джерело активності, спрямованої на об'єкт ${ }^{5}$.

\footnotetext{
${ }^{4}$ Предборсъка I.M., Ганаба С.О. Філософія історії : навчальний посібник. - Суми : Університетська книга, 2012. - С. 137.

${ }^{5}$ Дойчик М.В. Філософія історії: навчально-методичний посібник. - ІваноФранківськ : Симфонія форте, 2010. - С. 123.
} 
Іван Бойченко вживає поняття «соціально-історичний суб'єкт», підкреслюючи, що історія людства розвивається через дію об'єктивносуб'єктивних суспільних сил - економічних, соціальних, політичних, духовних, що виявляються у діях людей ${ }^{6}$. «Люди, народні маси шляхом свідомих цілеспрямованих дій, прояву ініціативи, активності, творчості не просто впливають на історію, але і формують, творять сам суспільно-історичний процес» ${ }^{7}$. У той же час, Тамара Ящук послуговується як поняттями «суб'єкт історичного процесу» та «суб'єкт історії», так і виразом «діяч історії» ${ }^{8}$.

Поряд з цим, у науковій літературі також можна зустріти поняття «áктор історії», під яким розуміють агента історичної політики У ролі «áкторів історії» виступають як державні інституції (президент, парламент, Національний банк України, Укрпошта, Український інститут національної пам'яті, архіви, музеї, уряд та місцеві органи самоврядування), так і недержавні організації (політичні партії, громадські організації, мережеві спільноти та засоби масової інформації). Особливе, однак часто не визначальне і підпорядковане місце серед агентів історичної політики, на думку Георгія Касьянова, займають самі історики. Касьянов зазначає, що «проблема вибору ролі може розглядатися у світлі такого попереднього висновку: у більшості випадків такого вибору немає. Більшість істориків просто рухається течією політичної кон'юнктури та “суспільного запиту”, забезпечуючи формування та ретрансляцію панівних дискурсів, і небезпідставно вважають це нормою» ${ }^{10}$.

Звісно, думки щодо ключового дієвця в історії у різні часи істотно відрізняються. Якщо спробувати їх класифікувати у цілому, то можна вирізнити дві групи: уявлення про аперсоналізованого творця історії та уявлення про персоналізованого дієвця.

Для першої групи характерно вбачати головного творця історії у якійсь надприродній нематеріальній сутності, котру людина не може сприймати безпосередньо органами чуття або розумом, однак здатна спостерігати і фіксувати їі вплив як на своє власне життя, так і на долю світу загалом. Наприклад, це може бути: Бог у авраамічних ре-

\footnotetext{
${ }^{6}$ Філософія історії : підручник / І.В. Бойченко [та ін.] - Харків : Прапор, 2006. - C. 505.

7 Див.: там само. - С. 507.

${ }^{8}$ Ящук Т.І. Філософія історії: Курс лекцій : навчальний посібник. - Київ : Либідь, 2004. - С. 385, 387, 403.

${ }^{9}$ Касъянов Г. Past continuous: історична політика 1980-х - 2000-х. Україна та сусіди. - Київ : Laurus, Антропос-Логос-Фільм, 2018. - С. 101.

10 Див.: там само. - С. 199.
} 
лігійних філософських традиціях (іудаїзм, християнство, іслам); доля та боги у давніх греків і римлян; абсолютний дух у філософії Гегеля.

До групи персоналізованого дієвця в історії можна віднести: окрему людину - людину з її прагненнями та інтересами (К. Маркс, Л. фон Мізес), видатну історичну постать (Т. Карлейль, Плутарх), правителя (Н. Макіавеллі, Светоній), харизматичного лідера (М. Вебер), пасіонарія (Л. Гумільов), надлюдину (Ф. Ніцше); суспільну групу - суспільний клас (К. Маркс, Ф. Енгельс, В. Ленін, П. Бурд'є, Р. Дарендорф), страту (П. Сорокін), еліту (В. Паретто, Г. Моска, Р. Міхельс), інтелігенцію (І. Франко, А. Тойнбі), соціальні рухи (А. Турен), «нову» інтелігенцію постіндустріального суспільства (Д. Белл, Дж. Гелбрейт, М. Кастельс, Е. Тоффлер); великі колективи - натовп та маси (Г. Лебон, Х. Ортегаi-Гассет, Е. Фромм, Г. Маркузе, Х. Арендт), народ (I. Гердер, Т. Гоббс, Дж. Локк, Ю. Габермас, Г. Гегель), нація (Е. Хобсбаум, Е. Гелнер, Е. Сміт), етнос (Л. Гумільов), раса (Ж.А. де Гобіно, Г. Лебон, Л. Гумплович), культурно-історичний тип (М. Данилевський), культура та/або цивілізація (О.Шпенглер, А. Тойнбі, С. Гантінгтон), людство як таке (В.С. Соловйов, Л.П. Карсавін, І. Гердер, Е. Тоффлер).

\section{Ключовий дієвець історії: великі колективи (спільноти)}

Поняття народ у контексті дієвця історії може мати три різні визначення: етнічне, політичне та соціальне. По-перше, народ як етнічна група або спільність людей. У цьому розумінні поняття народу збігається з поняттям нації в етнічному розумінні (етно-нація або етнічна нація.я). Для народу як етнічної групи чи етнічної нації визначальними є тези про спільне походження, мову і спільну «рідну» етнічну культуру (традиції, історичну пам'ять, релігію). Етнічна модель нації на сьогодні є характерною для країн Східної Європи та Близького Сходу. Ентоні Сміт наголошує, що у межах цього підходу націю розглядають як свого роду «надродину», члени якої, відповідно, відрізняються від решти людства своєю кревною спорідненістю.

Чи то людина зоставатиметься у своїй спільноті, чи то емігрує до іншої, вона завжди неминуче й органічно залишатиметься членом спільноти, в якій народилася, і довіку нестиме на собі її печать. Одне слово, нація - це передусім спільнота людей, об'єднаних спільним походженням. ${ }^{11}$

${ }^{11}$ Cміт Е.Д. Національна ідентичність. - Київ : Основи, 1994. - С. 21-22. 
Антоніна Колодій зазначає, що етнічні нації - ті народи, котрі вбачають у своїй етнокультурній окремішності головне джерело національної самоідентифікації і підставу для утворення власної держави, - виникають в умовах бездержавності, там, де рух за духовне відродження і політичну консолідацію передує утворенню національної держави і здійснюється під керівництвом духовно-інтелектуальної еліти, оскільки політична еліта в умовах чужоземного панування не має можливості розвинутися ${ }^{12}$.

Саме таке розуміння народу як основного дієвця в історії, якому притаманний певний унікальний і неповторний «народний характер», можна зустріти, наприклад, у працях німецького просвітника, мовознавця та філософа Іоганна Готфріда Гердера. У своїй праці Ідеї до філософії історії людства він стверджує:

Генетичний дух, характер народу - це загалом річ вражаюча та дивна. Його не можна ані пояснити, ані стерти з лиця Землі: він старий, як нація, старий, як грунт, на якому проживав народ. Брахмана не відірвати від його землі, і ніхто інший, вважає він, не заслуговує цієї священної природи. Таким є і китаєць, таким є і японець; за межами своєї країни вони - лоза, пересаджена невчасно. ${ }^{13}$

Гердер досить оптимістично дивиться у майбутне людства, наголошуючи, що людство у цілому постійно еволюціонує, стає більш гуманним. Розвиток гуманності в людині є сутністю і метою людської природи, заради досягнення якої бог передав долю людства у руки самих людей ${ }^{14}$.

По-друге, поняття народ позначає політико-правову спільність людей - усе населення тієї чи іншої країни незалежно від національноетнічної, соціальної, гендерної чи релігійної приналежності. У цьому розумінні поняття народ збігається з поняттям політичної нації, приналежність до якої визначається виключно громадянством. Такий підхід Сміт називає західною громадянською моделлю нації, для якої найбільш характерними ознаками нації є спільна правова система, юридична рівність, спільна громадянська культура та ідеологія (чуття правової і політичної спільноти).

Згідно з західною концепцією, саме юридичні й політичні права становлять найсуттєвіший елемент західної моделі нації. 3 цього випли-

${ }^{12}$ Колодій $A$. Ознаки нації як модерної соціокультурної і політичної спільноти [Електронний ресурс] / Авторський сайт Антоніни Колодій. - Режим доступу: https: //political-studies.com/?page_id $=344$

${ }^{13}$ Гердер И.Г. Идеи к философиии истории человечества. - Москва: Наука, 1977. - C. 315.

14 Див.: там само. - С. 429. 
ває мінімум взаємних прав та обов'язків членів нації і відповідне ненадання цих прав та обов'язків чужинцям. Випливає також і спільний кодекс законів, що стоять над місцевими законами, та інституції, що утверджують їх, суди останньої інстанції тощо. Не менш важливим є визнання, що в принципі всі члени нації юридично рівні, і навіть багатії й можновладці коряться законам батьківщини. ${ }^{15}$

Крім цього, нації повинні мати певну систему спільної культури та громадянської ідеології, низку спільних порозумінь і сподівань, почуттів та ідей, що пов'язують населення з його рідним краєм. Звичайно, західна модель нації також передбачає, що індивід має обов'язково належати до певної нації, однак вибір, до якої саме нації приєднуватися, здійснює сама людина, що не є можливим відповідно до етнічного розуміння нації. Підсумовуючи, Сміт пропонує наступне сучасне визначення націӥ: це сукупність людей, що має власну назву, свою історичну територію, спільні міфи та історичну пам'ять, спільну масову громадську культуру, спільну економіку і єдині юридичні права та обов'язки для усіх членів. Таким чином, до найголовніших рис національної ідентичності він відносить наступне: історична територія або рідний край; спільні міфи та історична пам'ять; спільна масова громадська культура; єдині юридичні права і обов'язки для усіх громадян; спільна економіка з можливістю вільно пересуватись у межах національної території ${ }^{16}$.

Витоки політико-правового підходу до поняття народу як ключового дієвця історії слід шукати у працях філософів-просвітників, зокрема у засновників концепції громадянського суспільства та суспільного договору. Так, наприклад, Джон Локк стверджує, що саме народ є джерелом політичної влади, утворюючи за згодою кожної окремої особи спільноту - державу, яка керується за згодою більшості. Відповідно, ми можемо продовжити думку Локка, наголошуючи, що згідно до його концепції, саме народ творить свою історію, виступає історичним дієвцем.

Оскільки люди, як було сказано, за природою усі вільні, рівні й незалежні, то нікого не можна вивести із цього стану і підкорити політичній владі іншого без його на те згоди. Єдиний спосіб відмовитися від своєї природної свободи та накласти на себе узи громадянського суспільства - це домовленість з іншими людьми про об'єднання у спільноту задля зручного, спокійного й мирного співжиття, надійного користування своєю власністю, а також більшої, ніж у тих, хто не живе у суспільстві, безпеки. Таке може здійснити будь-яка кількість людей,

${ }^{15}$ Cміт Е.Д. Національна ідентичність. - Київ : Основи, 1994. - С. 20.

${ }^{16}$ там само. - C. 20, 23. 
бо це не зашкоджує свободі інших, котрі, як і раніше, залишаються вільними у стані природи. Коли певна кількість людей погодилась таким чином утворити єдину спільноту чи систему врядування, то вони вже через це стають об'єднаними та утворюють єдиний політичний організм, у якому більшість має право діяти і вирішувати за решту. ${ }^{17}$

Зовсім нещодавно Юрген Габермас, осмислюючи демократичні зміни 1989-1990-х pр. - демократичні революції у державах Східної Європи, що призвели до падіння комуністичних режимів у цих країнах, а також аналізуючи процес об'єднання Німеччини, констатував цікавий факт: загальним лозунгом та обгрунтуванням, на основі якого відбувалися усі ці зміни, була теза - «цього хоче народ». Зокрема, у Східній Німеччині основним гаслом було: «Ми народ!», «Ми один народ!». Габермас вже тоді назвав історичні зміни у східноєвропейському регіоні «революцією навздогін» і у своєму однойменному есеї Революиія навздогін формулює поняття «народ-виборець», який виступає у ролі суб'єкта (тобто дієвця) цієї надолужувальної революції ${ }^{18}$.

По-третє, поняття народ можна розуміти у соціальному плані як народні маси. На нашу думку, до такого розуміння схиляються Карл Маркс та Фрідрих Енгельс. У роботі Німецька ідеологія зазначається, що історія являє собою послідовну зміну окремих поколінь, кожне 3 яких використовує матеріали, капітали, виробничі сили, надані йому усіма попередніми поколіннями. У зв'язку з цим дане покоління, 3 однієї сторони, продовжує успадковану діяльність у повністю змінених умовах, а з іншої - видозмінює старі умови життя за допомогою повністю зміненої діяльності. «Обставини у такій же мірі творять людей, у якій люди творять обставини» ${ }^{19}$. Маркс і Енгельс застосовують поняття «маса людей» як означення для маси робочої сили - пролетаріату, тобто людей, котрі живуть лише завдяки своїй праці. Відповідно до їхньої позиції, пролетаріат складає «основну масу людей» ${ }^{20}$. Маркса та Енгельса можна навіть вважати одними із засновників теорії масового суспільства та теорії еліт. Так, наприклад, вони стверджують:

Люди завойовували собі свободу кожного разу настільки, наскільки це диктувалося їм і допускалося не їхнім ідеалом людини, а існуючими виробничими силами. В основі усих завоювань свободи, котрі

\footnotetext{
17 Локк Дж. Два трактати про врядування. - Київ : Видавництво Соломії Павличко ОСНОВИ, 2001. - С. 180.

18 Див.: Буден Б. Зона переходу. Про кінець посткомунізму. - Київ : Медуза, 2013. - C. 54-56.

${ }^{19}$ Маркс K., Енгельс Ф. Немецкая идеология. - Москва: Политиздат, 1988. C. 34,37 .

20 Див.: там само. - С. $33,40$.
} 
відбувалися до сих пір, полягали однак обмежені виробничі сили; обумовлене цими виробничими силами, недостатне для усього суспільства виробництво робило можливим розвиток лише у такий спосіб, що одні особи задовольняли свої потреби за рахунок інших, і тому одні - меншість - отримували монополію розвитку, інші ж - більшість унаслідок постійної боротьби за задоволення найнеобхідніших потреб були на певний час (тобто до створення нових революціонізуючих виробничих сил) позбавлені можливості будь-якого розвитку. Отже, суспільство розвивалося до сих пір завжди у межах протилежності, котра у давнину була протилежністю між вільними і рабами, у середні віки - між дворянством та кріпосними, у новий час - між буржуазією і пролетаріатом. Цим пояснюється, з однієї сторони, ненормальний, «нелюдський» спосіб задоволення пригніченим класом своїх потреб, а з іншої - вузькість рамок, у межах яких відбувався розвиток суспільних відносин, а з ним і усього пануючого класу; ця обмеженість розвитку полягає, таким чином, не лише у тому, що один клас відсторонюється від розвитку, але й у розумовій обмеженості того класу, який робить це відсторонення. ${ }^{21}$

Цікаво, що у такому розумінні поняття народ (як народні маси або низи суспільства) використовуе також один із відомих дослідників теорії націй і націоналізмів Ернст Гелнер. Він висуває досить незвичне припущення щодо походження сучасних націй, а саме: нації вигадують інтелектуали, свідомо нав'язуючи високі стандартизовані зразки культури народним масам. Гелнер наголошує, що, зазвичай націоналізм презентує себе як уособлення народної культури - «йде під прапором народної культури», а свою символіку формує з ідеї здорового, первозданного, активного способу життя селянства, народу.

Націоналізм, по суті, є нав'язуванням високої культури суспільству, в якому раніше серед більшості, а часом і всього населення панували культури низькі. Це означає загальне, повсюдне запровадження через школи науково впорядкованої та апробованої мови, кодифікованої для забезпечення достатньо цілісного бюрократичного і технологічного комунікативного простору. Це розбудова масового, анонімного суспільства, що складається із маси взаємозамінних індивідів-атомів, які поєднуються в єдине ціле спільною культурою. Воно заступає місце попередньої складної системи локальних груп, що спиралися на народні культури, які самотужки самовідтворювалися на локальному рівні. Ось що відбувається насправді. ${ }^{22}$

Отже, з точки зору Гелнера, нації формуються елітою, виникнення націй та національних держав не становило взаємообумовленого процесу, як традиційно стверджує націоналізм, а скоріше мало випадковий

21 Див.: там само. - C. 405.

22 Гелнер Е. Нації та націоналізм; Націоналізм. - Київ : Таксон, 2003. - С. 93-94. 
характер. Загальні суспільні умови переходу від традиційного аграрного суспільства до індустріального зумовили «необхідність у стандартизованих, однорідних культурах, підтримка яким забезпечується централізовано; ці культури охоплюють усе населення, а не елітарні меншості - тоді виникає ситуація, коли чітко окреслені, санкціоновані освітою та уніфіковані культури утворюють майже єдиний тип спільноти, з яким люди так охоче і часом так пристрасно ототожнюють себе. Тепер культури постають як цілком природні депозитарії політичної легітимності. Лише з цього часу починає здаватися, нібито будьяка розбіжність культурних кордонів з межами політичних одиниць $є$ скандалом» ${ }^{23}$. Що ж перетворило цю «випадкову» за своєю природою ідею нації на універсальну норму сучасного світу? Гелнер відповідає, що це, по-перше, культурна спільність (двоє людей належать до однієї нації тоді і лише тоді, коли вони належать до однієї культури - спільної системи ідей, символів, асоціацій, способів поведінки та спілкування) та, по-друге, добровільне і взаємне визнання одне одного (двоє людей належать до однієї нації тоді й лише тоді, коли вони визнають одне одного як таких, що належать до однієї нації) ${ }^{24}$. Зазначена думка Гелнера істотно перегукується з позицією Бенедикта Андерсона, який у свої праці Уявлені спільноти визначає націю як уявлену політичну спільноту.

Вона є уявленою, оскільки члени навіть найменшої нації ніколи не будуть знати більшість своїх побратимів-по-нації, зустрічатися з ними чи навіть чути про них, у той час як у мисленні кожного з них живе образ їхньої спільності ${ }^{25}$.

У ХХ ст. на історичну арену у ролі дієвця історії виходять великі маси людей (маса або натовп), ті самі організовані й стандартизовані засобом системи освіти спільноти («народ»), відірвані від своїх локальних культур за Гелнером ${ }^{26}$. Ці величезні маси людей являють собою не стільки «робітничі маси», як у Маркса, скільки становлять собою маси звичайних людей - пересічних громадян певної країни. Хосе Ортега-іГассет наголошує, що маса - це «середня людина» ${ }^{27}$. На його думку,

23 Див.: там само. - - С. 91.

24 Див.: там само. - - C. 35-36.

${ }^{25}$ Андерсон Б. Воображаемые сообщества. Размышления об истоках и распространении национализма. - Москва : КАНОН-пресс-Ц, Кучково поле, 2001. - С. 2829 .

${ }^{26}$ Gellner E. Selected Philosophical Themes. Volume II. Contemporary Thought and Politics. - London and New York : Routledge : Taylor and Francis Group, 2003. - P. 144146.

${ }^{27}$ Opтега-и-Гассет X. Восстание масс. - Москва: ООО Издательство АСТ, 2002. 
маса являє собою психологічний феномен, а не фізичний. Щоб відчути масу як психологічну реальність, не потрібно великого скупчення людей, достатньо спостерігати за однією єдиною людиною, можна легко визначити, маса це чи ні.

Маса - будь-хто і кожен, хто ані у добрі, ані у злі не міряе себе особливою мірою, а відчуває таким же, «як усі», і не тільки не є пригніченим через це, але й задоволений власною невідмітністю. ${ }^{28}$

Ортега-і-Гассет не протиставляє масу правлячій еліті, навпаки він наголошує, що особливістю ХХ ст. є той факт, що при владі також знаходяться представники маси. Людина маси - це певний історичний тип людини. Тому сучасні держави та уряди також живуть одним днем, вони не планують на довгу перспективу, не мають життєвої програми. Вони настільки всесильні, що звели до мінімуму саму можливість опозиції. Сутність урядування зведена ними до постійних спроб просто тікати від проблем, а не вирішувати їх.

Маса - це ті, хто пливе за течією і позбавлений орієнтирів. Тому масова людина не створює нічого, навіть, коли їі можливості величезні. ${ }^{29}$

Розвинуте індустріальне стандартизоване суспільство потребувало стандартизованої людини. Герберт Маркузе називає таку людину «одномірною», тобто такою, що мислить і діє відповідно до спрощених стандартів, нав'язаних їй ззовні масовою культурою, яка, у свою чергу, продукується і нав'язується системою масового виробництва ${ }^{30}$. Одномірність мислення та поведінки перетворюється на стиль життя людини масового суспільства. Економічний розвиток і підвищення рівня життя широких мас населення фактично компенсує втрату свободи та індивідуальності. Права і свободи, котрі були життєво необхідними факторами становлення індустріального суспільства (свобода думки, слова, совісті, свобода підприємництва), сама можливість критики існуючої суспільної системи після ствердження нової, більш продуктивної і раціональної, втрачають своє значення і дієвість ${ }^{31}$.

На перший погляд здається, що маси як сукупності пересічних людей зі спрощеним мисленням і поведінкою, керованих державними структурами та економічними групами впливу у принципі не здатні

- С. 18-19.

${ }^{28}$ Див.: там само. - - С. 19.

29 Див.: там само. - - C. 49.

${ }^{30}$ Marcuse H. One-Dimensional Man. Studies in the ideology of advanced industrial society. - London and New York: Routledge Classics, 2002. - P. 14.

31 Див.: там само. - - P. 11, 4. 
бути дієвцем історії, однак філософський аналіз історії XX ст. демонструє, що саме такі «середні» або «одномірні» люди - маси - стали потужною силою авторитарних і тоталітарних рухів у різних країнах, своїм існуванням обумовили ствердження тоталітарних режимів. Ханна Арендт зазначає:

Тоталітарні рухи можливі усюди, де наявні маси, які з тієї чи іншої причини набули бажання до політичної організації. Маси тримаються разом не завдяки усвідомленню спільних інтересів і їм бракує характерної класової структурованості, котра відображується у визначених, обмежених та досяжних цілях. Термін 'маси' застосовується лише там, де ми маємо справу з людьми, котрі або через їхню кількість, або через байдужість, або завдяки поєднанню обох причин не можуть бути об'єднані у будь-яку організацію, засновану на спільному інтересі, у політичні партії чи в органах місцевого самоврядування, професіональні організації чи профспілки. ${ }^{32}$

Основною характеристикою людини маси є не жорстокість чи відсталість, а їі ізольованість та відсутність нормальних соціальних взаємин $^{33}$. У такій ситуації людина прагне подолати цей стан самотності у будь-який спосіб. Еріх Фромм у праці Втеча від свободи вирізняе три можливі шляхи: авторитаризм (відмова від незалежності власної особистості з метою злиття з кимось або чимось поза власним «я», що $е$ джерелом сили, котрою сам індивід не володіє), руйнування (як відчайдушна спроба врятуватися від світу, аби не бути ним розчавленим) та конформізм (відмова від своєї індивідуальності на користь типу особистості, котрий пропонує людині пануюча культура; бути «таким як усі» є найбільш прийнятним шляхом втечі від свободи для більшості нормальних індивідів сучасного світу). Авторитаризм як підпорядкування і злиття з вождем чи лідером та конформізм як прагнення бути «як усі», тобто злиття з загалом, залишаються працюючими механізмами втечі від соціальної дійсності до сьогодні 34 . Арендт вдало демонструє цю хворобливу єдність вождя і мас, цитуючи дуже показову фразу Адольфа Гітлера, котрий в одному зі своїх виступів наголошує: «Усе, чим ви є, ви є завдяки мені; усе, чим я є, я є лише завдяки вам» 35 . За своєю суттю, тоталітарний лідер є лише функціонером мас,

${ }^{32}$ Arendt H. The Origins of Totalitarianism. - San Diego-New York-London: A Harvest Book: Harcourt Brace and Company, 1976. - P. 311.

${ }^{33}$ Див.: там само. - - P. 317.

${ }^{34}$ Фромм Е. Бегство от свободы. - Москва: Издательство АСТ, 2018. - С. 141, $176,182$.

${ }^{35}$ Цит. див.: Arendt H. The Origins of Totalitarianism. - San Diego-New YorkLondon: A Harvest Book: Harcourt Brace and Company, 1976. - P. 432. 
якими він керує; він не обов'язково має мати нестримну жагу до влади і владарювання. Тоталітарний лідер у такій самій мірі залежить від «волі» мас (яку він собою уособлює), як і маси залежать від нього. За відсутності лідера масам бракувало би зовнішнього представлення і вони залишалися б просто аморфним стадом ${ }^{36}$.

Арендт звертає увагу до пропаганди як засобу психологічного впливу на маси, ідеологічної обробки та маніпуляції з метою тримати маси у покорі і скеровувати у потрібному напрямку, обов'язково посилаючись на «наукові» обгрунтування, природні закони історичного розвитку чи приховані сили, які гарантують «правильність» руху у щасливе майбутнє. «Пропаганда становить собою єдиний i, можливо, найважливіший інструмент тоталітаризму для боротьби 3 нетоталітарним світом» ${ }^{37}$. Цю думку підтримує також Гюстав Лебон, підкреслюючи, що юрба не мислить раціонально і не сприймає аргументацію, вона сприймає лише образи - «мислить образами». Нездатність натовпу правильно розмірковувати заважає йому критично відноситися до будь-чого і, відповідно, мати певне судження про будь-що та відрізняти істину від омани. Судження натовпу завжди $є$ нав'язаними йому зовні, вони не є результатом всебічного обговорення. «Хто володіє мистецтвом вражати уяву натовпу, той володіє мистецтвом ним керувати», - робить висновок Лебон ${ }^{38}$.

Лебон разом з Жозефом де Гобіно представляють також расовий підхід у трактуванні історичного розвитку. Расові теорії були сформульовані у XIX - початку XX ст. і являють собою приклад формального перенесення принципів еволюційного вчення Чарльза Дарвіна на історію людства. Будучи продуктом свого часу, концепція рас як расової нерівності відіграли істотну роль у світовій історії (рабство, сегрегація, апартеїд), частково до сьогодні залишаючись конфліктним фактором соціальної взаємодії. Наприклад, де Гобіно у праці Досвід про нерівність людсъких рас зазначає, що раси є структурними елементами людства. Він вирізняє раси першої формації (прямі потомки Адама, про яких нам нічого не відомо) та раси другої формації - білу (семіти й кавказці), чорну (хаміти), жовту (алтайці, монголи, фіни, татари), котрі являють собою «три чистих і первородних елементи, з яких складається людство» ${ }^{39}$. Також $є$ певна кількість так званих «змішаних»

36 Див там само: Р. 325.

37 Див там само: Р. 344-345.

38 Лебон Г. Психология толп // Психология толп. - Москва : Институт психологии РАН, Издательство КСП+, 1998. - С. 155-162.

${ }^{39}$ Гобино ЖК.А. де. Опыт о неравенстве человеческих рас. - Москва: ОЛМА- 
pac, які виникають у результаті історичних контактів чистих рас. Кожна раса володіє певним набором культурних властивостей, задатків та здібностей, тому цивілізації, засновані ними, дуже різні між собою. Фактично, кожна раса творить власну культуру, яка не може бути перейнята представниками іншої раси. Друга важлива теза у концепції раси де Гобіно: нерівність рас у фізичних й інтелектуальних здібностях i, відповідно, нерівність створених ними культур ${ }^{40}$.

Примітно, що Лебон взагалі ставить саму ідею рівності народів і культур під питання, підкреслюючи, що «вже майже півтора століття пройшло з того часу, коли поети та філософи, які з надзвичайним невіглаством відносилися до первісної історії людини, різноманіття їі душевного ладу і законів спадковості, закинули у світ ідею рівності людей і рас» ${ }^{41}$. Згідно 3 думкою Лебона, людина є завжди представником раси, яка у свою чергу є постійною сутністю, котра не підвладна часу $^{42}$.

Моральні та інтелектуальні особливості, сукупність яких відображують душу народу, являють собою синтез усього його минулого, спадок усіх його пращурів і спонукальні причини його поведінки. В окремих індивідуумів тієї ж раси вони здаються настільки ж мінливими, як і риси обличчя; але спостереження показують, що більшість індивідуумів цієї раси завжди володіють певною відомою кількістю загальних психологічних особливостей, котрі є настільки ж стійкими, як анатомічні ознаки, відповідно до яких класифікуються види. [...] Психологічні особливості відтворюються спадковістю з правильністю і постійністю. Цей агрегат загальних психологічних особливостей становить собою те, що обгрунтовано називають національним характером. Їх сукупність утворює середній тип, що дає можливість визначити народ. ${ }^{43}$

Расові ідеї та уявлення про нерівність рас (представників різних рас) між собою в інтелектуальних здібностях, потенційних можливостях розвитку, правах і свободах знайшли своє відображення у расистській теорії націонал-соціалізму у Німеччині, де було здійснено практичний експеримент по втіленню расистських ідей у життя з трагічними наслідками для людей «нижчих рас» - євреїв, ромів та не-арійців у цілому. Однак, слід зазначити, що расистські теорії були притаманні

ПРЕСС, 2000. - С. 138-139.

40 Див.: там само. - С. 143, 160-163.

41 Лебон Г. Психология толп // Психология толп. - Москва : Институт психологи

РАН, Издательство КСП+, 1998. - С. 15.

42 Див.: там само. - С. 23-24.

43 Див.: там само. - С. 22. 
не лише німецькому націоналізму, але й багатьом іншим націоналістичним течіям у Європі початку і середини минулого століття. Так, зокрема, якщо говорити про теоретиків українського націоналізму, то можна згадати Дмитра Донцова. У своїй праці Націоналізм він обгрунтовує доктрину «вольового націоналізму», відповідно до якого: «теорії загального братерства народів нічого не варті, коли не береться вигляд на історичне становище, на щабель суспільного розвою поодиноких народів. [. . . ] Історія стверджує, що панувати все могли лише раси, натхнуті великим безінтересовним патосом ("теольогічною" ідеєю) великим фанатизмом, який є неминучою складовою частиною кожної ідеї, що глядить у будуччину. Але й навпаки, раси і ідеї, які хочуть грати ролю в історії, мають гукати не до світової "справедливості", лише до своєї волі і здібностей - пхнути історію наперед, працювати для "поступу"», під яким він розуміє «право сильних рас організувати людий і народи для зміцнення істнуючої культури і цивілізації» 44 .

Історичний процес можна розглядати як систему етносів, що постійно розвивається і змінюе свою конфігурацію. Слово «етнос» у перекладі з грецької означає «народ». Етнос являє собою складний суспільно-біологічний феномен, що виникає як біологічна одиниця людської популяції, яка протягом свого існування й розвитку набуває соціальних ознак. У залежності від конкретних соціально-історичних умов, етнос може характеризуватись такими ознаками, як спільне уявлення про час і місце свого виникнення, антропологічні відмінності, культурні, ментальні та мовні особливості, а також через самоідентифікацію його представників ${ }^{45}$. Юліан Бромлей надає наступне визначення етносу: стійка міжпоколінна сукупність людей, котра історично сформувалася на певній території та володіє не просто спільними рисами, але й відносно стабільними особливостями культури (включаючи мову) і психіки, а також усвідомленням своєї єдності і відмінності від усіх інших подібних утворень (самосвідомістю), зафіксованому у самоназві (етнонімі). ${ }^{46}$

Як правило, структурно у системі етносу можна вирізнити протоетнос (первинна стадія розвитку етносу, його зародження), субетносмалочисельна етнічна спільнота, яка виникає в особливих історичних умовах у межах більшої етнічної спільноти (етносу) і зберігає певні відмінності у культурі і мові, плекає свої, притаманні лише їй, тради-

44 Донцов Д. Націоналізм. - Львів : Видавництво Нове життя, 1926. - С. 209.

${ }^{45}$ Радей A.C. Етнос і нація. Аналіз дефініцій // Мультиверсум. Філософський альманах. - 2015. - Вип. 1-2 (139-140). - С. 74.

${ }^{46}$ Бромлей Ю.В. Очерки теории етноса. - Москва: Наука, 1983. - С. 57. 
ції, звичаї й суттєво відрізняється своєрідним етнічним менталітетом; метаетнос (мегаетнос або суперетнос) - етнічна система, що складається із декількох етносів, які сформувалися в одному ландшафтному регіоні і є близькими у генетичному і культурному сенсі. ${ }^{47}$ Наприклад, у структурі українського етносу можна чітко вирізнити місцеві субетноси поліщуків, русинів, литвинів, лемків, бойків, гуцулів, а сам український етнос у свою чергу входить у якості складового елементу слов'янського метаетносу (або суперетносу).

Цікаву теорію етногенезу пропонує Лев Гумільов, який наголошує, що людину не можна назвати ані стадною, ані індивідуальною твариною, людина завжди існує у колективі, який, залежно від кута зору, розглядається або як суспільство, або як народність. Етнос являє собою колектив людей, який протиставляє себе усім іншим колективам за принципом: «ми такі й такі, а усі інші - інші» ${ }^{48}$. Таке протиставлення є характерним для усіх епох та країн, наприклад, греки і варвари, китайці (жителі Серединної держави) та ху (варварська периферія), європейці-католики у середні віки і нечестиві (православні), православні та нехристи (нехристияни разом з католиками). Сутність етносу становить певний унікальний стереотип поведінки, який відрізняє його від усіх інших. Кожен етнос, зазначає Гумільов, виникає у результаті поєднання двох і більше складових компонентів. Тому часто можна як зустріти двомовні чи, навіть, трьохмовні етноси, так і ряд різних етносів, котрі говорять однією мовою. Наприклад, французи говорять на чотирьох мовах - французькій, кельтській (бретонській), баскській та провансальській, однак це не заважає їхній етнічній єдності. Важливим фактором етногенезу є природний ландшафт: однорідний по ландшафтам регіон стабілізує етноси, які його населяють, різнорідні (у тому числі - штучно різнорідні) - стимулюють зміни, що призводять до нових етнічних утворень. Тому Європа, Євразійський континент та Близький Схід, де має місце поєднання моря, гір, степу, пустелі, гірських лісів і річних долин, являли і являють собою надзвичайно сприятливе географічне середовище для утворення нових етносів ${ }^{49}$.

Гумільов пропонує досить вдалу аналогію: природу слід розглядати як багатоманітність ландшафтів, а людство як мозаїку етносів ${ }^{50}$.

47 Eвтух В.Б. Етнічність: енциклопедичний довідник. - Київ: Фенікс, 2012. C. 130 .

48 Гумилев Л.Н. Этносфера: История людей и история природы. - Москва: Экопрос, 1993. - С. $39,41$.

49 Див.: там само. - С. 99-100, 107-108.

50 Див.: там само. - С. 104. 
Загальною ознакою для динамічного стану будь-якого етносу, на його думку, є здатність популяції, що виникла, до так званого «наднапруження», яке проявляється або у перетворенні природи, або у міграціях, теж пов'язаних зі зміною ландшафту на новоосвоєних територіях, або у підвищеній інтелектуальній, військовій, організаційнодержавницькій, торговій та іншій діяльності. Майже усі відомі нам етноси згруповані у своєрідні конструкції - «культури», або «суперетнічні цілісності». Першопочатково етнос займає район, у якому він з'явився і взаємодіє, не завжди мирно, зі своїми «однолітками». Пізніше, набравши сили, він мігрує, залишивши на батьківщині частину свого складу. При цьому він обов'язково втрачає значну частину початкового запасу енергії. Деякі етнічні групи гинуть, інші, втрапивши у ізоляцію від сильних сусідів, перетворюються на ізольовані, реліктові етноси, у котрих немає ані приросту населення, ані саморозвитку суспільного буття, а модифікації відбуваються лише при взаємодії сусідів $^{51}$. Визначальною для успішного розвитку кожного етносу $є$ така його властивість, як пасіонарність - непереборне внутрішне прагнення невеликої кількості людей до надзвичайно активної цілеспрямованої діяльності, завжди пов'язаної зі зміною оточення (етнічного чи природного), незважаючи на видимі ризики для свого життя. 3 точки зору Гумільова, це, безумовно, є відхиленням від видової норми поведінки, тому що зазначений імпульс майже завжди суперечить інстинкту самозбереження. Для етики і норм поведінки пасіонарного етносу є характерним принцип переваги колективних інтересів над індивідуальними, навіть над бажанням жити і обов'язком піклуватися про власних дітей ${ }^{52}$.

Представників культурно-цивілізаційних концепцій історії - Миколу Данилевського, Освальда Шпенглера та Арнольда Тойнбі також можна віднести до прихильників «масштабних» колективних дієвців історії. У концепціях цього типу ним виступає окрема культура або цивілізація (культурно-історичний тип), яка проходить у своєму розвитку послідовно етапи зародження, становлення, розквіту та занепаду i, таким чином, творить історичний поступ та одночасно являє собою структурну одиницю історичного процесу ${ }^{53}$. Кожна культурноцивілізаційна теорія має свої особливості. Наприклад, Шпенглер й

${ }^{51}$ Див.: там само. - С. 112.

52 Див.: там само. - С. 120-121.

${ }_{53}$ Мішалова O.В. Ідея прогресу та моделі розгортання історичного процесу // Актуальні проблеми духовності: зб. наук. праць. - Кривий Ріг: КДПУ, 2018. Вип. 19. - С. 175-180. 
Тойнбі наділяють культуру та/або цивілізацію наддержавним регіональним статусом і не ототожнюють їх з певним народом чи державним утворенням, тоді як Данилевський свої культурно-історичні типи пов'язує саме з діяльністю певних народів. Він вирізняє, по-перше, позитивно-діяльні культурні типи або самобутні цивілізації (до них входять ті народи, котрі змогли створити власні культури; наприклад, єгипетський, грецький, римський тощо); по-друге, негативні діячі в історії (народи, котрі не спромоглися створити самобутні культури, але «допомогли» загибелі старих вмираючих культур, у чому і полягала їхня місія; наприклад, гуни, монголи або турки); по-третє, народи, що за різних причин зупинилися у своєму розвитку на певному етапі і з часом перетворилися на матеріал для етнографічних досліджень (як правило, вони урізноманітнюють собою культурне багатство культурно-історичних типів, однак власної історичної індивідуальності не досягають $)^{54}$. Отже, підсумовує Данилевський, «правильне, згідне із законами природної системи групування історичних явищ приводить нас до того висновку, що до сих пір розвиток людства йшов не інакше як через посередництво самобутніх культурно-історичних типів, які відповідають великим племенам, тобто через посередництво самобутніх національних груп» ${ }^{55}$.

До культурно-цивілізаційного підходу можна також віднести сучасну теорію зіткнення цивілізацій Самюеля Хантингтона, на думку якого історія людства - це історія цивілізації. Цивілізації становлять собою культурні, а не політичні сутності ${ }^{56}$. Відповідно до його позиції, досить довгий час - від XV до XX ст. - національні держави Заходу (Велика Британія, Франція, Іспанія, Австрія, Пруссія, Німеччина, Сполучені Штати Америки) створили багатополярну міжнародну систему у межах європейської цивілізації, взаємодіючи, конкуруючи та воюючи між собою. 3 іншого боку, вони розширювали свій вплив на інші регіони світу (цивілізації), завойовуючи і колонізуючи їх, стверджуючи таким чином домінування західної цивілізації над усіма іншими. У XX ст. світ ідеологічно був поділений на два табори: демократичний (економічно заможні демократичні країни на чолі зі Сполученими Штатами Америки) та комуністичний (економічно дещо бідніші комуністичні країни на чолі з Радянським Союзом), між якими під час так званої «холодної війни» постійно йшла політична боротьба та

54 Данилевский Н.Я. Россия и Европа. - Москва : Книга, 1991. - С. 89.

55 Див.: там само. - C. 112-113.

${ }^{56}$ Huntington S.P. The Clash of Civilization and the Remaking of World Order. New York: Simon and Schuster, 1996. - P. 40, 44. 
військове протистояння, тобто світ був біполярним. У кінці 80-х - початку 90-х pp. XX ст. з падінням комуністичної системи і закінченням холодної війни світ уперше в історії став глобально багатополярним і мультицивілізаційним.

У світі після холодної війни найважливішими відмінностями між народами є не ідеологічні, політичні чи економічні, а культурні. Люди і народи намагаються відповісти на одне з найголовніших питань, 3 яким людям доводиться мати справу: хто ми $е$ ? I вони відповідають на це питання у традиційний для людей спосіб, звертаючись до речей, котрі для них важливі. Люди визначають себе з точки зору походження, релігії, мови, історії, цінностей, звичаїв та інституцій. Вони ідентифікують себе з культурними групами: племенами, етнічними групами, релігійними спільнотами, націями і на найвищому рівні з цивілізаціями. ${ }^{57}$

У цьому новому світі, на думку Хантінгтона, провідну роль відіграють дев'ять потужних цивілізацій (західна, китайська, японська, ісламська, індуїстська, буддистська, православна, латиноамериканська, африканська), між якими неминуче відбуватимуться «зіткнення», спричинені культурними відмінностями. Конфлікти у сучасному світі - це «культурні конфлікти». Тому вивчення цих культурноцивілізаційних відмінностей є необхідним завданням для успішного руху у майбутне. У цілому найважливішою характеристикою сучасного світу є суттєвий «зсув» балансу сил: довге панування західної цивілізації змінюється домінуванням не-західних цивілізацій ${ }^{58}$.

До найбільш масштабного дієвця історії також можна відносити людство у цілому, як це роблять, наприклад, представники російської релігійної філософії - Володимир Соловйов, Сергій Булгаков, Лев Данилевсьвін та Микола Бердяєв. Так, Соловйов уявляє людство як єдину істоту, що складається із взаємопов'язаних елементів, як єдиний живий організм, спрямований у своєму розвитку до єднання з Богом. Осмислюючи сутність історичного процесу як цілеспрямований рух усього людства до всеєднання (сакральний зміст історії), він, тим не менш, розрізняє у площині профанного (земного) світу окремі можливі шляхи цього поступу, пов'язані з релігійним чинником. Тому поряд з людством як головним дієвцем в історії у філософії Соловйова з'являються свого роду «релігійно-культурні світи»: християнський (західна і православна варіаціі), буддистський, ісламський тощо. ${ }^{59}$

\footnotetext{
57 Див.: там само. - Р. 21.

58 Див.: там само. - Р. 28-29.

${ }^{59}$ Павленко Ю. Історія світової цивілізації: соціокультурний розвиток людства: навчальний посібник. - Київ : Либідь, 2000. - С. 108-110.
} 
Карсавін у своїх розмірковуваннях також засновується на християнських позиціях, вирізняючи два плани історичного процесу: профанний (земний) та сакральний (божественний), єдність яких розкривається в акті боговтілення і земному житті Ісуса Христа. Останнє виступає головною подією всесвітньої історії. Карсавін наголошує на особливій місії християнської церкви: введення людства до боголюдства, що розуміється у площині не лише історичної, але й космічної еволюції ${ }^{60}$. Зміст історії полягає у розвитку людства як всеєдиного, позапросторового та позачасового «суб'єкта» («стяженно-всеєдине» або «грішне» людство) ${ }^{61}$. Справді цікавим у концепції Карсавіна є введені ним поняття «історичної колективної особистості» або «колективної індивідуальності», які є індивідуалізаціями людства як основного дієвця в історії. До таких індивідуалізацій він відносить не лише культуру, народ, соціальну групу, окремого індивіда, а також системи світогляду, етичні та/або правові системи, поняття «Відродження», «людина епохи Відродження» («середня» людина будь-якої епохи) або «середньовічний купець» ${ }^{62}$. «Суб'єкт історичного розвитку - всеєдине людство, людство як конкретна позачасова та позапросторова єдність усіх своїх моментів або індивідуалізацій, аж до умовно-останньої, до конкретного індивідуума». ${ }^{63}$

\section{Ключовий дієвець історії: особистість}

Відповідно до визначення Тетяни Воропаєвої, історична особистість - це видатний державний, національний, політичний, громадський, релігійний, культурно-мистецький або науковий діяч, котрий справив великий вплив на перебіг суспільно-політичних, соціальноекономічних, культурно-історичних подій, які визначили на багато років уперед шляхи розвитку держави, нації, країни, суспільства (чи усього людства). Своєю масштабною перетворюючою соціокультурною діяльністю історична особистість здійснює суттєві перспективні зміни у житті соціуму, залишаючи надзвичайний духовний вплив на нащадків і незгладимий слід у матеріальній та духовній культурі, а також у історичній пам'яті нащадків. Воропаєва також наголошує, що найбільші духовні творіння часто виникають у перехідні епохи, ви-

60 Див.: там само. - С. 112.

${ }^{61}$ Карсавин Л.П. Философия истории. - Санкт-Петербург: АО КОМПЛЕКТ, 1993. - C. 88-89, 97.

62 Див.: там само. - С. 88, 100.

63 Див.: там само. - С. 102. 
находи, інновації та відкриття, здійснені історичними особистостями, часто визнавалися суспільством лише після їхньої смерті, а видатні люди найчастіше гинули у досить молодому віці, оскільки хитрість, підступність і брутальність використовувалися проти них в усі історичні епохи. Попри це, особисті якості видатних діячів, їхні розум та воля, духовність і світогляд, симпатії та антипатії справляли неабиякий вплив на перебіг подій, історичний процес і концентровано відтворювали специфічний колорит своєї історичної епохи ${ }^{64}$.

Масштабна перетворююча діяльність історичної особистості, що призводить до кардинальної реорганізації буття (як реального, так і ідеального), може бути оцінена за наступними критеріями: по-перше, особистий вибір у важливій суспільно значущій чи конфліктній ситуації як здійснення вільного та відповідального волевиявлення; по-друге, вклад у інших людей (продовження себе у дітях, учнях чи вихованцях, наступниках та продовжувачах справи), тобто мається на увазі особистісний вплив на представників інших поколінь, наповнення новим змістом і новими цінностями знань та почуттів інших людей, залучення їх до діяльності, необхідної для поступу держави, націй та суспільства; по-трете, вихід «за межі» ситуативних вимог, рольових приписів, наявних стандартних завдань і норм, що означає подолання буденності, стереотипності, уніфікованості, власних пристрастей, пристосовництва, творчість та інноваційна діяльність у науці, мистецтві, політиці чи економіці, тобто діяльність, у результаті якої відбувається докорінний злам застарілих форм, що заважають прогресивному розвитку суспільства; по-четверте, особисті вчинки та діяння як прояв свідомої соціальної творчості, суб'єктивної життєвої позиції, моральності, духовності, альтруїзму, патріотизму, громадянської позиції, які дають адекватну відповідь на «виклики часу»; по-п'яте, суспільне несення або служіння, що означає передачу ключових для розвитку суспільства ідей, ідеалів, норм, цінностей, пріоритетів у культурноцивілізаційній, релігійній чи мистецькій сферах, а також особистий внесок у громадську справу, у розвиток культури, науки і техніки; по-шосте, подвижництво і героїзм; по-сьоме, особиста самопожертва, обумовлена служінням вищим суспільним та духовним цінностям ${ }^{65}$.

Дойчик пропонує розглянути обставини, від яких залежить роль видатної особистості у суспільному розвитку. Наприклад, це можуть бути: (1) здібності, талант чи геніальність цієї особистості; (2) її стано-

${ }^{64}$ Bоропаєва T. Роль особистості в українській історії крізь призму біографістики // Українська біографістика. - 2016. - № 14. - С. 61.

65 Див.: там само. - С. 63-64. 
вище у суспільстві (у політичному та економічному житті, у державі загалом); (3) партія чи група впливу, до якої входить та/або очолює ця особистість, звідси - більший/менший, прогресивний/консервативний вплив на історичний поступ; (4) розуміння історичних завдань, що постали перед конкретним суспільством, і оптимальних шляхів їхнього вирішення; (5) наявність або відсутність об'єктивних умов для здійснення відповідних змін ${ }^{66}$.

Найбільш яскравим представником особистісного підходу у розумінні ключового дієвця в історії є Томас Карлейль, котрий у праці Герої, шанування героїв та героїчне в історї̈ наголошує, що історія світу - це біографія великих людей ${ }^{67}$.

\begin{abstract}
Всесвітня історія, історія того, що людина здійснила у цьому світі, на мою думку, є у своїй сутності історією Великих Людей, котрі прокладали собі дорогу тут, на землі. Вони були лідерами людства, створювали моделі, самі виступали у якості зразків i, у широкому сенсі, є творцями усього того, що великі маси людей примудрилися зробити або досягти. Усі речі, здійснені у цьому світі, являють собою, власне, зовнішній матеріальний результат, практичну реалізацію та втілення Думок, що належали великим людям, посланим у наш світ. ${ }^{68}$
\end{abstract}

Відповідно до позиції Карлейля, суспільство тримається на шануванні героїв, яке відображується у лояльності - вірності й відданості суспільства до видатних людей («героїв» або «вчителів») та їхніх дій. Тому завдання кожної епохи полягає у тому, щоб знайти таку «достатньо велику людину», тобто достатньо мудру, добру і відважну, щоб визначити вимоги часу та зуміти провести людей правильною дорогою у майбутнє. Вони є запорукою «спасіння» кожної епохи ${ }^{69}$. Надзвичайно цікавим і продуктивним аспектом бачення видатної історичної особистості у праці Карлейля є той факт, що «велика людина» не асоціюється ним лише з особою правителя (як правило, монарха). Карлейль розробляє своєрідну класифікацію дієвців історії (шість «типів героїв») і включає до ряду видатних людей (героїв, які творять історію): політичних лідерів (наприклад, Наполеон Бонапарт, Олівер Кромвель), релігійних пророків (до прикладу, засновник ісламу Мухаммед), героїв божественного походження (таких, як Одін, Ісус

${ }^{66}$ Дойчик М.В. Філософія історії: навчально-методичний посібник. - ІваноФранківськ : Симфонія форте, 2010. - С. 124.

${ }^{67}$ Carlyle T. On Heroes, Hero-Worship, and the Heroic in History. - New Haven and London: Yale University Press, 2013. - Р. 30. (Карлейль Т. Герои, почитание героев и героическое в истории. - Москва: Эксмо, 2008. - С. 19.)

68 Див.: там само. - Р. 21. (С. 7.)

69 Див.: там само. - Р. 28-30. (С. 17-19.) 
Христос), проповідників (наприклад, Мартін Лютер чи Джон Нокс), nоетів (таких, як Данте Аліг'єрі, Вільям Шекспір) та писъменників (до прикладу, Роберт Бернс та Семюель Джонсон) ${ }^{70}$.

Традиційно як ключового дієвця історії розглядали саме владну особу (правителя, носія влади за правом народження чи правом вибору), політичного діяча і військовокомандувача одночасно. Так, можна згадати відомі праці «Порівняльні життєописи» Плутарха та «Життєопис дванадцяти цезарів» Светонія. Останній, наприклад, наводить майже крилату фразу Луція Корнелія Сулли щодо молодого Цезаря: «один Цезарь вартує багатьох Маріїв» ${ }^{71}$.

Ніколло Макіавеллі пише, навіть, спеціальний трактат-настанову «Державець», у якій надає докладні настанови для будь-якого правителя, котрий хоче бути успішним і залишити своє ім'я в історії своєї країни. Він чітко формулює достатньо сміливі й провокативні ідеї: підкреслює важливість для державця прихильності народу у більшій мірі, аніж знаті (симпатії народу більш триваліші за підтримку знаті, котра може зрадити у будь-яку мить); наголошує, що слід прагнути одночасно і любові народу, і послуху, заснованому на страху, однак краще, щоб правителя боялися, аніж любили, якщо доведеться обирати (але безумовно слід уникати ненависті та презирства) ${ }^{72}$. Макіавеллі порівнює видатного державця з левом і лисом у одній особі, оскільки

слід бути в очах людей співчутливим, вірним слову, милостивим, щирим, благочестивим - і бути таким насправді, але внутрішньо слід зберігати готовність проявити і протилежні якості, якщо це буде необхідно. Слід розуміти, що державець, особливо новий, не може виконувати усе те, за що людей вважають гарними, тому що заради збереження держави він часто буває змушений йти проти свого слова, проти милосердя, доброти та благочестя. Тому у душі він завжди повинен бути готовий до того, щоб змінити напрямок, якщо події набудуть іншого ходу, аніж передбачалось, і вітер фортуни подує у іншу сторону, тобто, як вже було сказано, по можливості не віддалятися від добра, але за необхідності не цуратися зла. ${ }^{73}$

Про державців судять завжди за результатами їхнього правління, тому державець має застосовувати будь-які засоби для досягнення успіху для себе і своєї країни. Важливим для досягнення цього, на

70 Див.: там само. - Р. 21, 162, 51, 31, 104, 77, 132. (С. 8, 199, 47, 20, 119, 82, 158.)

${ }^{71}$ Светоний Транквилл Гай. Жизнеописание двенадцати цезарей. - Москва-Ленінград : ACADEMIA, 1933. - С. 40.

${ }^{72}$ Макиавелли Н. Государь // Макиавелли Н. Избранные сочинения. - Москва : Худож. лит., 1982. - С. 328-329, 349, 353.

73 Див.: там само. - С. 352. 
думку Макіавеллі, є як «особиста доблесть» державця, так і випадок («воля фортуни» чи «милість долі»), котрий полягає у вдалих обставинах ${ }^{74}$.

Обдумуючи життя і подвиги цих мужів, ми упевнюємося у тому, що доля послала їм лише випадок, тобто надала матеріал, якому можна було надати будь-яку форму: якщо б не було такого випадку, їхня доблесть згасла б, не знайшовши застосування; якби вони не володіли доблестю, випадок з'явився б марно. [...] Отже, кожному з цих людей випав щасливий випадок, але лише їхня видатна доблесть дозволила їм розкрити смисл випадку, завдяки чому батьківщини їх прославлялися і знайшли щастя. ${ }^{75}$

Георг Гегель, подібно до Карлейля, також створює свого роду класифікацію дієвців історії. Це, насамперед, окремі індивіди (котрими рухають приватні інтереси, пристрасті, егоїзм), народи (кожному 3 яких притаманний певний «дух народу»), держави (суспільство і держава становлять собою передумови здійснення свободи громадян), всесвітнъо-історичні особистості (котрі засновують держави, скеровують людей у майбутнє) ${ }^{76}$. Гегель робить важливе уточнення, поділяючи народи на історичні (котрі мали чи мають свою державу) та неісторичні (бездержавні народи).

У всесвітній історії може йтися лише про ті народи, котрі утворюють державу. Оскільки слід знати, що держава являє собою здійснення свободи, тобто абсолютно остаточної мети, що вона існує сама для себе; далі, важливо знати, що вся цінність людини, вся їі духовна дійсність, існує виключно завдяки державі. [...] Тому що істинне є єдністю всезагальної і суб'єктивної волі, а всезагальне існує у державі, у законах, в загальних і розумних визначеннях. Держава є божественною ідеєю як вона існує на землі. 77

Історичні народи, котрі спромоглися створити державу як запоруку свого всебічного розвитку і свободи, зробили це не самі, а завдяки видатним людям - героям, що їх очолювали. Всесвітньо-історичні особистості являють собою «духовних керівників» людства, що здатні повести за собою інших. Це, як правило, видатні політичні діячі, які, однак, у свою чергу виступають лише «знаряддям» у здійсненні своєї мети Абсолютним Духом. Видатні особистості насправді можуть навіть не усвідомлювати цієї своєї ролі провідників волі Світового розуму. Їхнє життя сповнене тяжкої праці, вони позбавлені звичайних

74 Див.: там само. - С. 316-319.

75 Див.: там само. - С. 316.

${ }^{76}$ Гегель Г.В.Ф. Лекции по философии истории. - Санкт-Петербург : Наука, 1993 - С. 73-75, 68, 99, 92, 81, 90.

77 Див.: там само. - С. 90. 
людських радощів і змушені боротися з великою кількістю труднощів на шляху слідування до єдиної цілі (така цілеспрямованість виступає їхньюю характерною рисою), а після досягнення мети вони, за словами Гегеля, «відпадають ніби "пусті оболонки"» 78 .

На думку Гегеля, всесвітня історія здійснюється у «духовній сфері», тобто у сфері мислення. У світі пануе розум, відповідно, всесвітньо-історичний процес здійснюється розумно. Таке бачення основної засади історії бере свій початок з гегелівського вчення про світ, де розум є субстанцією світу - «тим, завдяки чому і у чому уся дійсність має своє буття» ${ }^{79}$. Отже, ключовим дієвцем в історії є Світовий розум, який використовує видатних людей і вправно грає на бажаннях, потребах та інтересах великих мас населення, скеровуючи їх до визначеної мети, що становить собою «хитрість» історичного розуму $^{80}$. Ототожнюючи Світовий розум з Богом та добром, Гегель наголошує:

Бог править світом; зміст його правління, здійснення його плану є всесвітня історія. Філософія прагне зрозуміти цей план, тому що лише те, що з нього здійснено, є дійсним; те, що не відповідає йому, являє собою лише гниле існування. Перед чистим світлом цієї божественної ідеї, яка не є лише ідеалом, зникає ілюзія, ніби світ становить світ, позбавлений розумності, безглуздий процес. ${ }^{81}$

У ролі самостійного дієвця історії також може виступати звичайна людина зі своїми планами, бажаннями та діями. Наприклад, Людвіг фон Мізес наголошує, що людина володіє свободою волі і від природи є діяльною істотою ${ }^{82}$. Історія твориться людьми, вона являє собою результат свідомих, зумисних дій індивідів, як великих, так і нікчемних, тобто історичний процес $є$ «збірним» результатом зумисних дій усіх індивідів.

Будь-яка дія щось додає до історії, здійснює вплив на хід майбутніх подій і у цьому сенсі є історичним фактом. Найтривіальніше виконання щоденної рутини апатичними людьми становить історичну даність не у меншій мірі, аніж найбільш вражаючі нововведення генія. Історична роль простої людини полягає у тому, щоб вносити свою лепту у структуру величезної влади звичаю. ${ }^{83}$

\footnotetext{
78 Див.: там само. - С. $82-84$.

79 Див.: там само. - С. $70,64$.

80 Див.: там само. - С. 77.

81 Див.: там само. - С. 87.

${ }^{82}$ Мизес Л. Теория и история: Интерпретация социально-экономической эволюции. - Москва : ЮНИТИ-ДАНА, 2001. - С. 131.

83 Див.: там само. - С. 142.
} 
Мiзес ні в якому разі не заперечує ваги видатної особистості в історії, однак підкреслюе, що жодна людина своїми діями не здатна скеровувати хід подій протягом більш ніж відносно короткого проміжку часу. Крім того, будь-яка людина (і велика, і пересічна) живе і діє у межах історичних обставин своєї епохи, які визначаються усіма ідеями та подіями попередніх епох, а також ідеями й подіями їі часу. Державний діяч може досягти успіху лише тією мірою, наскільки його плани відповідають загальному настрою його епохи, тобто ідеям, котрі володіють думками його співгромадян. Отже, політик може стати лідером лише у тому випадку, якщо він готовий вести людей тим шляхом, яким вони хочуть іти, і до тієї мети, якої вони прагнуть досягти. Якщо державець наважується йти проти суспільної думки, він приречений на невдачу. У зовсім іншій ситуації знаходяться науковці, митці та письменники, оскільки вони не настільки залежать від ідей свого часу, а покликані йти далі цих ідей, привносити щось нове і творче. Однак, як зазначає Мізес, «праця генія також вплетена у послідовність історичних подій, обумовлена досягненнями попередніх поколінь і являє собою просто главу в еволюції ідей» 84 .

Праці Фрідріха Ніцше сповнені зневаги і відвертої огиди до звичайних пересічних людей, яких він називає «невиліковно посередніми», однак саме такі індивіди є «людьми майбутнього, котрі переживуть теперішнє», що, на його думку, призведе до загибелі культури ${ }^{85}$. У праці По той бік добра $i$ зла представлено поділ людей на сильних і слабких, для яких характерні відмінні моральні настанови - мораль пануючих і мораль рабів.

Люди знатної породи відчувають себе мірилом цінностей, вони не потребують схвалення, вони говорять: «що є шкідливим для мене, те шкідливо саме по собі», вони вважають себе саме тим, що наділяє речі гідністю, вони творять цінності. [...] Така порода людей пишається тим, що створена не для співчуття. [...] Знатні і хоробрі люди надто далекі від моралі, яка вбачає у співчутті або в альтруїстичних вчинках [...] відмінну ознаку морального; віра у самого себе, гордість самим собою, глибока ворожість та іронія по відношенню до «безкорисливості» так само відносяться до моралі знатних, як і легке презирство й обережність у відношенні до співчуття і «сердечності» [.. . ] Раб недоброзичливо дивиться на чесноти сильного [.. ] ] він оточує себе ореолом і висуває на передній план такі якості, які слугують для полегшення існування стражденних: таким чином отримують повагу співчуття, [...] сердечність, терпіння, старанність, лагідність і дружелюбність, -

84 Див.: там само. - С. $142,136$.

${ }^{85}$ Huцие Ф. По ту сторону добра и зла // Ницше Ф. Сочинения: в 2-х томах. Москва: Мысль, 1990. - Т. 2. - С. 387. 
тому що тут це найкорисніші якості і майже єдині засоби, що надають змогу витримати тягар існування. Мораль рабів у своїй сутності є мораллю корисності. ${ }^{86}$

Ніцше наполягає, що люди «панівної касти» хижі за своєю природою - люди з не надламаною силою волі і жагою до влади - творять історію та вищу культуру на цій землі. Вони знищували більш слабкі, моральні й миролюбні раси, що займалися сільським господарством і скотарством, та старі культури, які знаходилися на етапі застою і занепаду, втрачаючи останні залишки життєвої сили. «Каста знатних була спочатку завжди кастою варварів: її перевага полягала, перш за все, не у фізичній силі, а в душевній, - це були більш цільні люди (що на будь-якому ступені розвитку означає також і «більш цільні звірі»)» 87 . До типу надлюдини або «вищої натури», що належить до меншості у суспільстві, Ніцше, наприклад, відносить Наполеона, якого він називає «синтезом нелюдини і надлюдини» ${ }^{8}$. Надлюдині, справжньому дієвцю в історії, протистоїть більшість слабких «ручних людей», котрі мають нахабність вважати себе метою, вершиною і сенсом історії, звідки, на думку Ніцше, бере початок надлишок невдач, хворобливість, втома, якими відрізняється сучасна для нього Європа ${ }^{89}$.

Цікавий факт: Гумільов також використовує постать Наполеона для ілюстрації своєї теорії пасіонарності, а саме як приклад справжнього пасіонарія - надзвичайно активного, діяльного і безкомпромісного індивіда, котрий змінює світ навколо себе (як природний, так і соціальний), задаючи пасіонарний імпульс цілому етносу. Пасіонарність як властивість притаманна усім людям, але у різний мірі, і проявляється у різних якостях: владолюбство, гордість, марнославство, жадібність, котрі у рівній мірі породжують і подвиги, і злочини, ведуть до створення чи руйнування, однак найважливішою властивістю пасіонарних людей є прагнення до зміни і перетворення оточення. Імпульс пасіонарності може бути настільки сильним, що носії цієї ознаки - пасіонарії - не спроможні розрахувати наслідки своїх вчинків і, навіть, передбачаючи свою загибель, втриматися від їх здійснення.

Яскравим прикладом пасіонарія може служити Наполеон I. Після єгипетського походу він став настільки багатим, що міг би прожити залишок життя, не працюючи. Обиватель так би і вчинив. Наполеон же

${ }^{86}$ Див.: там само. - С. 382-383.

87 Див.: там само. - С. 258.

${ }^{88}$ Нuцше Ф. К генеалогии морали // Ницше Ф. Сочинения: в 2-х томах. - Москва: Мысль, 1990. - Т.2.- С. 437.

89 Див.: там само. - С. 429. 
обрав надзвичайно тяжкий тягар, з величезним ризиком та сумним кінцем. Модусом його пасіонарності було владолюбство. Його марнославні маршали обмежилися прагненням до почестей. ${ }^{90}$

Як дієвця історії з надзвичайним талантом також слід розглядати харизматичного лідера у концепції типів панування Макса Вебера. У відомій праці Господарство $i$ суспільство він зазначає, що можна виділити три ідеальні типи легітимного панування (і лідерства): раціональне (грунтується на раціональній основі, тобто на переконаності у правильності зафіксованих порядків і правил), традиційне (тримається на повсякденній вірі у святість існуючих з давнини традицій і у легітимність, заснованого на цій традиції авторитету) і харизматичне (засновується на харизматичній основі, тобто переконаності у святості, героїчності чи надзвичайній досконалості певної персони або встановленого нею порядку $)^{91}$.

Харизма, згідно Вебера, є певною якістю особистості, завдяки якій ця людина вважається наділеною надзвичайними, надлюдськими або виключними, нікому більше не властивими силами та здібностями чи вважається посланцем богів, тому має бути лідером. У давніх культурах природа харизми визначалася як магічно обумовлена і приписувалася пророкам, лікарям, мудрим суддям, знаменитим мисливцям i військовим героям. Значимість харизми визначається вільним визнанням й прийняттям підданими харизматичності свого лідера, що, однак, вимагає певного підтвердження - дива, а також передбачає віру в одкровення, поклоніння перед героєм, надію на вождя. За усієї своєї неоднозначності, харизматичне панування є революційним за своєю роллю і метою, воно руйнує прийняті (часто застарілі) правила і зразки поведінки ${ }^{92}$.

Харизма - це велика революційна сила у пов'язані традиціями епохи. На відміну від також революціонізуючої сили ratio, котра діє ззовні (або шляхом зміни життєвих обставин і проблем і завдяки цьому відношення до них, або шляхом інтелектуалізації), харизма може стати трансформацією зсередини, що відбувається у зв'язку з бідою чи захватом і такою, що веде до різкої зміни напрямку думки і дії, до повної зміни усіх установок як щодо окремих форм життя, так і на світ загалом. ${ }^{93}$

${ }^{90}$ Гумилев Л.Н. Этносфера: История людей и история природы. - Москва: Экопрос, 1993. - С. 121.

${ }^{91}$ Вебер М. Хозяйство и общество: очерки понимающей социологии в 4 т. - Москва: Изд. дом Высшей школы экономики, 2016. - Т. 1. - С. 254-255.

92 Див.: там само. - С. 279-280, 282.

93 Див.: там само. - С. 283. 


\section{Ключовий дієвець історії: суспільна група}

Суспільна група, або страта - відносно стійка спільність людей, які мають спільні цінності, життєві орієнтації та інтереси і відрізняються певною сукупність соціально-психологічних ознак та практик поведінки. До суспільних груп як дієвців історії можна віднести клас, еліту, творчу інтелектуальну меншість, інтелігенцію, суспільний рух.

Якщо у концепції Вебера революційну роль у трансформації суспільства відіграє харизматичний лідер, то, з точки зору Маркса і Енгельса, революціонізуючою силою у суспільстві наділені соціальні класи. Масові зміни людей (людської свідомості) можливі лише у практичному русі - революції. Відповідно, «революція потрібна не лише тому, що жодним іншим способом неможливо подолати пануючий клас, але й тому, що долаючий клас тільки у революції може скинути з себе весь старий непотріб і бути здатним створити нову суспільну основу» ${ }^{94}$.

У надзвичайно провокативній праці Маніфест комуністичної парmiї Маркс та Енгельс наголошують, що історія усіх суспільств є історією боротьби класів: вільний - раб, патрицій - плебей, поміщик - кріпак, майстер - підмайстер, буржуа - пролетар, тобто гнобитель і пригноблений перебувають у вічному антагонізмі один до одного, ведуть невпинну, то приховану, то явну боротьбу, яка завжди закінчується революційною перебудовою всієї суспільної будови або загальною загибеллю класів, котрі вели між собою боротьбу. Найбільш революційним класом в історії суспільства Маркс і Енгельс вважають буржуазію, котра менш ніж за сто років свого класового панування створила більш численні і більш масштабні продуктивні сили, аніж усі минулі покоління разом узяті: підкорення сил природи, машинне виробництво, застосування хімії у промисловості і землеробстві, пароплавство, залізниці, електричний телеграф, освоєння для землеробства цілих частин світу, пристосування річок для судноплавства, концентрація величезних мас населення у містах. Крім того, буржуазія зруйнувала усі феодальні, патріархальні, ідилічні відносини, не залишивши ніякого іншого зв'язку між людьми, окрім взаємних інтересів (економічного характеру). Буржуазія позбавила священного ореолу всі роди діяльності, які до того часу вважалися почесними і на які дивилися з побожним трепетом. Лікаря, юриста, священника, поета, людину науки вона пере-

${ }^{94}$ Маркс K., Енгельс Ф. Немецкая идеология. - Москва: Политиздат, 1988. C. 36 . 
творила на своїх платних найманих працівників ${ }^{95}$.

Однак, з часом буржуазія, котра здійснила революційний прорив в усіх сферах суспільно життя, втрачає свій революційний запал і перетворюється на силу, яка гальмує історичний поступ.

Сучасне буржуазне суспільство, з його буржуазними відносинами виробництва і обміну, буржуазними відносинами власності, що немов чарами створило такі могутні засоби виробництва і обміну, схоже на чарівника, що уже неспроможний справитися з підземними силами, які він викликав своїми заклинаннями. Ось уже кілька десятиріч історія промисловості і торгівля являє собою лише історію збурення сучасних продуктивних сил проти сучасних виробничих відносин, проти тих відносин власності, які є умовою існування буржуазї та її панування. Досить вказати на торгівельні кризи, які, періодично повертаючись, дедалі грізніше ставлять під сумнів існування всього буржуазного суспільства. ${ }^{96}$

Причину торгівельних криз, під час яких суспільства ніби «відкидаються» назад, у стан варварства, Маркс і Енгельс вбачають у тому, що продуктивні сили суспільства більше не слугують розвиткові буржуазних відносин власності, а навпаки, вони стали непомірно великими для цих відносин, тобто буржуазні відносини власності стримують розвиток продуктивних сил, які ж вони свого часу створили. У цій ситуації цікаво, як клас буржуазії намагається долати кризи: шляхом створення все більш усебічних і більш руйнівних криз, а також зменшенням засобів протидіяння ним ${ }^{97}$, що ми, ймовірно, спостерігаємо й у наш час. Тому Маркс та Енгельс покладають великі надії на клас пролетаріїв і комуністичну революцію, яку вони покликані здійснити, щоб знищити панування будь-яких класів разом з самими класами i національностями ${ }^{98}$.

Тим не менш, концепція суспільного класу Маркса й Енгельса не є однозначною, оскільки вони чітко розуміють, що окремі індивіди утворюють клас лише у тій мірі, в якій вони ведуть спільну боротьбу проти будь-якого іншого класу, в іншій ситуації вони свідомо ведуть боротьбу один з одним як конкуренти, переслідують свій власний інтерес ${ }^{99}$.

${ }^{95}$ Маркс К., Енгельс Ф. Маніфест Комуністичної партії // Кирилюк Ф.М. Історія зарубіжних політичних вчень Нової доби : [навч. посіб.]. - Київ : Центр учбової літератури, 2008. - С. 310-312.

96 Див.: там само. - С. 312-313.

97 Див.: там само. - С. 313.

${ }_{98}$ Маркс K., Енгельс Ф. Немецкая идеология. - Москва: Политиздат, 1988. C. 36 .

99 Див.: там само. - С. $60,30$. 
Відповідно, більш засадничим дієвцем в історії у марксистському матеріалістичному ї̈ трактуванні є людина з її власними інтересами, яка, будучи істотою соціальною, творить історію у різноманітних соціальних формаціях, на чому, як правило, завжди наголошують щирі прихильники марксистської філософії ${ }^{100}$.

На сьогодні розуміння класу як дієвої сили історичного розвитку серйозно видозмінено. Так, наприклад, Ральф Дарендорф під суспільним класом розуміє конфліктну групу, тобто спільноту з усвідомленими спільними інтересами, і розробляє гнучку класифікацію соціальних конфліктів та конфліктних груп.

У кожному суспільстві існує велика кількість соціальних конфліктів, наприклад, між конфесіями, між частинами країни, між керівниками i керованими. Вони можуть бути відділені один від одного у такий спосіб, що сторони кожного окремого конфлікту як такі представлені лише у ньому; вони можуть бути напластовані у такий спосіб, що ці фронти повторюються у різних конфліктах, коли конфесія А, частина країни Q і правляча група змішуються в одну велику «сторону». У кожному суспільстві існує велика кількість інституціональних порядків - держава й економіка, право та армія, виховання і церква. Ці порядки можуть бути відносно незалежними, а політичні, економічні, юридичні, військові, педагогічні і релігійні керуючі групи - не ідентичні; але, можливо, що одна й та сама група задає тон в усіх cфepax. ${ }^{101}$

Про правлячий клас (або політичний клас) як ключового дієвця історії говорить також Гаетано Моска, розуміючи під ним добре організовану і підготовлену до державних справ меншість суспільства. Не використовуючи поняття «еліта», Моска, тим не менш, є одним з основних авторів теорії еліт поряд з Вільфредо Парето і Робертом Міхельсом. Класичною є цитата із праці Моска Правлячий клас:

Серед незмінних фактів і тенденцій, які ми можемо спостерігати у всіх політичних організмах, один момент є абсолютно очевидним, навіть, при найбільш випадковому погляді. У всіх суспільствах (починаючи від мало розвинутих чи таких, що ледве досягли цивілізації, до найбільш розвинутих і могутніх) існують два класи людей - клас правлячих і клас тих, ким правлять. Перший клас, завжди менш чисельний, виконує усі політичні функції, монополізує владу і використовує переваги, які надає влада у той час, як другий, більш чисельний клас, спрямовується і контролюється першим у такий спосіб, що на сьогодні

100 Див.: Encyclopedia of Marxism : Agency [Електронний ресурс]. - Режим доступу: https://www.marxists.org/glossary/terms/a/g.htm . - (дата доступу: 13.06.2020).

101 Дарендорф Р. Элементы теории социального конфликта // Социологические исследования. - 1994. - № 5. - С. 144. 
є більш-менш законним, більш-менш добровільним та насильницьким, і забезпечує першим, принаймні так виглядає, матеріальні засоби існування та інструменти, необхідні для життєдіяльності політичного організму. ${ }^{102}$

Моска наголошує, що меншість завжди буде більш організованою, аніж більшість, і у цьому їі основна перевага над більшістю (яка завжди є розосередженою), однак крім цього для представників пануючого класу також є характерними такі якості, які забезпечують їм матеріальні та інтелектуальні переваги і, навіть, моральну першість. Звичайно, доступ до правлячого класу вихідців із бідних верств населення є обмеженою, тому що публічність, гарна освіта, спеціальна підготовка, військова служба чи більш високий статус у церкві переважно належать вихідцям із заможних верств. До того ж, правлячий клас завжди прагне стати спадковим хоча б по факту, якщо не за законом, але рано чи пізно політичний клас занепадає, оскільки починає втрачати ті властивості, завдяки яким він отримав і утримував владу. Правильніше буде сказати, що старий політичний клас просто перестає відповідати умовам часу, оскільки, наприклад, з'являються нові джерела здобуття багатства у суспільстві, з'являється нова релігія або занепадає стара, зростає важливість спеціальних знань, розповсюдження нових ідей. Усе це призводить до трансформації політичного класу ${ }^{103}$. Моска називає це «оновленням» або «революцією», у процесі якої окремі індивіди - більш активні, амбіційні, розумні, більш енергійні та практичні - піднімаються по соціальній драбині з самого низу до самого верху. Якщо процес оновлення політичного класу починається, то його вже неможливо спинити чи законсервувати. Таким чином, новий правлячий клас, реалізуючи себе і свої інтереси, рухає суспільство вперед. Однак, Моска підсумовує свої розмірковування досить риторичним питанням: у які періоди суспільство є більш щасливим - у періоди соціальної стабільності й кристалізації (панування певного політичного класу) чи у періоди оновлення і трансформації (котрі дають можливість усім спробувати змінити свій соціальний статус і досягти більш високої позиції у суспільстві) $?^{104}$

Власне термін «еліта» вводить у науковий обіг Вільфредо Парето, який пропонує вирізняти дві страти у структурі будь-якого соціуму: нижча страта (клас, який не являє собою еліту) та вищу страту -

102 Mosca G. The Ruling Class. - New York and London: McGraw-Hill Book Company, 1939. - P. 50.

${ }^{103}$ Ibid. P. 53, 58, 61, 65, 68.

104 Див.: там само. - Р. 67-68. 
клас обраних або еліту (яка у свою чергу складається із двох частин - правлячу і неправлячу еліти). Чіткого критерію для віднесення певної людини до тієї чи іншої страти Парето не надає тому, що не існує таких екзаменів, які б визначили місце індивіда у певному класі, але зазначає, що під «елітою» він має на увазі осіб, які демонструють високі показники активності й ефективності у своїй сфері діяльності ${ }^{105}$. Як і Моска, Парето також підкреслює постійну необхідність циркуляції еліти, оскільки її замкненість веде до того, що у ній накопичується великий відсоток деградованих елементів, що веде до порушення суспільної рівноваги, оскільки керувати повинні найкращі, і у кінцікінців може призвести до загибелі усієї нації. В ідеалі еліта повинна постійно знаходитися у стані трансформації, Парето навіть порівнює цей процес із річкою, яка постійно у русі (більш або менш поступовому, іноді стрімкому і непередбачуваному). Причини революцій він вбачає у тому, що у вищих класах накопичується велика кількість «елементів поганої якості» через уповільнення циркуляції еліт або через якісь інші причини ${ }^{106}$. Аристократії не зберігаються, робить висновок Парето, якими б не були причини їхнього занепаду, очевидним є факт, через деякий час вони зникають (змінюються).

Історія - це кладовище аристократій. Афіняни були аристократією по відношенню до іншої частини населення - до метеків і рабів, але вони щезли, не залишивши нащадків. Зникли різноманітні аристократії давнього Риму. Щезли аристократії варварів. Де тепер у Франції можна зустріти нащадків завойовників франків? Генеалогії англійських лордів надзвичайно точні: дуже невелика кількість сімей виводять своє коріння від сподвижників Вільгельма Завойовника. У Німеччині нинішня аристократія походить в основному від васалів давніх сеньйорів. Населення європейських країн надзвичайно зросло протягом декількох останніх століть. Зрозуміло, що аристократії не зросли у тій самій пропорції. ${ }^{107}$

Роберт Міхельс обирає для позначення активної пануючої меншості у суспільстві термін «олігархія», підкреслюючи, що насправді в історії ми зустрічаємось не з вічною боротьбою аристократій і демократій чи боротьбою класів, а з політичною боротьбою старої меншості, котра прагне зберегти своє фактичне панування, та нової амбіційної меншості, яка намагається здобути владу або шляхом злиття зі старою елітою, або знищивши їі. Відповідно, будь-які розмови про панування

105 Парето В. Компендиум по общей социологии. - Москва: Издательский дом ГУ ВШЭ, 2008. - С. 308-309.

106 Див.: там само. - С. 314.

107 Див.: там само. - С. 313. 
мас, народне представництво, громадянські права, державу та націю - це просто описові фрази, які відповідають юридичному принципу, однак не відповідають жодним реально існуючим фактам суспільного життя ${ }^{108}$. Прицьому, Міхельс наголошує, що демократія не суперечить пануванню олігархії, котра являє собою сутність партійного устрою і демократичних режимів.

Демократичні партії, навіть якщо вони керовані олігархами, без сумніву здатні впливати на державу у демократичному сенсі ${ }^{109}$.

Політична партія, таким чином, виступає інструментом олігархії (керуючої меншості) для організації, впливу і контролю електоральних мас, котрі у своїй більшості є політично індиферентними і пасивними. Політична організація (партія) надає владу, однак влада завжди $\epsilon$ консервативною і контрольованою олігархією (так званий «залізний закон олігархії» $)^{110}$.

До представників теорії еліт можна з повним правом віднести Арнольда Тойнбі, одного із засновників культурно-цивілізаційних концепцій історії. У своїй відомій праці Дослідження історії він обстоює досить цікавий механізм існування та розвитку будь-якої цивілізації - «виклик - відповідь»: цивілізація у своєму розвитку постійно зустрічається з різного роду викликами (наприклад, зовнішня навала чи внутрішньополітична, культурна або економічна криза) і за умови, що вона здатна дати адекватну «відповідь», тобто вирішити суспільну проблему, цивілізація продовжує своє існування, а якщо відповідного вирішення проблеми не буде знайдено, цивілізація руйнується. На думку Тойнбі, у будь-якому суспільстві є люди - творча меншість, які здатні запропонувати основній масі людей шлях виходу із будь-якої складної історичної ситуації, однак до цих людей, як правило, не дуже дослухаються і часто знищують як морально, так і фізично.

Сам факт, що розвиток цивілізацій - це справа рук творчих індивідів або творчих меншин, має своєю передумовою те, що нетворча більшість залишатиметься позаду, аж поки першопрохідці винайдуть засіб підтягти ар'єргард до власних далеко висунутих уперед позицій. [...] Цивілізації, які перебувають у процесі розвитку, відрізняються від примітивних суспільств насамперед тим, що у їхньому суспільному організмі відбувається ніби внутрішній рух-бродіння творчих індивідуальностей. [.. ] ] У кожній цивілізації, захопленій процесом розвитку,

${ }^{108}$ Michels R. Political Parties: A Sociological Study of the Oligarchical Tendencies of Modern Democracy. - New Brunswick (USA) and London (U.K.) : Transaction Publishers, 1999. - P. 342.

109 Див.: там само. - Р. 333.

110 Див.: там само. - Р. 333-334, 85. 
переважна більшість індивідів і далі перебувають у стані стагнації, характерному для статичних примітивних суспільств. Ба більше; у розвинутій цивілізації основна маса народу, попри зовнішній лак освіти, підлягає тим самим пристрастям, що й первісні люди. В цьому явищі ми знаходимо підтвердження відомої сентенції, що людська вдача ніколи не змінюється. Особистості вищого порядку, генії, містики чи надлюди - назвіть їх, як вам хочеться, - це тільки дріжджі, які бродять у казані, заповненому пересічним людством. ${ }^{111}$

Елітарні погляди були характерні також для ряду українських мислителів. Наприклад, відомий своїми консервативними політичними поглядами В'ячеслав Липинський вбачав у спадковій монархії найкращий державний устрій для української незалежної держави і був переконаний, що реалізувати цей проєкт має національна аристократія «провідники і організатори нації». У праці Листи до братів-хліборобів він наголошуе:

Така група, чи такі групи людей в кожній нації дійсно існують, це ми побачимо, коли уважно глянемо на життя націй. В кожній з них є більша або менша, така або - в залежності од історичної епохи та відмінних умов існування - інша група людей, що кермує нацією, стоючи на чолі їі політичних організаційних установ, що витворює певні культурні, моральні, політичні і цивілізаційні вартости, які потім присвоює собі ціла нація, і якими ця нація живе і держиться ${ }^{112}$.

Слід підкреслити, що Липинський говорить про аристократію як про найкращих на «даний момент» людей, оскільки вони є організаторами, правителями і керманичами нації ${ }^{113}$, що суперечить принципу спадковості, характерному для традиційної аристократії. Важливими ознаками національної аристократії, на його думку, мають бути: вміння самоорганізуватися (тобто вміння обмежити свої індивідуалістичні інстинкти), вміння домовлятися (аби утворити національну єдність і подолати характерну для українського політичного життя егоцентричну анархію - Ахілесову п'яту України, про яку знають і яку постійно використовують сусіди для її поневолення) ${ }^{114}$.

Коли місцевими спільними силами старих і нових «панів» (нащадками колишньої правлячої верстви і представниками «свідомої», бажаючої собі влади, верстви нової) об'єднаними біля традиційного символу

111 тойнбі А. Дослідження історії : у 2 т. - Київ : Основи, 1995. - Т. 1. - С. 219.

112 Липинсъкий В. Листи до братів-хліборобів. Про ідею і організацію українського монархізму // Липинський В. Повне зібрання творів, архівів, студій : у 25 т. Київ - Філадельфія : Інститут Східноєвропейських досліджень НАНУ; Східноєвропейський дослідний інститут, 1995. - Т. 6., Кн. 1. - С. 130.

113 Див.: там само. - С. 131

114 Липинсъкий В. Покликання «варягів», чи орґанізація хліборобів? - Нью Йорк: Видавнича Корпорація Булава, 1954. - С. 85, 99, 111-112. 
Держави і Нації - Гетьманства - буде здавлений перший український бунт проти власної Української Влади - підстава панування Москви на Україні буде знищена. Політичним союзом Гетьманська Українська Держава позбавить Москву законної можливості йти війною на Україну, а фактичної можливості втручання у внутрішні українські справи Москва буде позбавлена внутрішньою державною силою українською, потрібною для здавленя власними українськими руками місцевої української анархії. ${ }^{115}$

Донцов у своїх розмірковуваннях прямо спирається на теорію еліт Вільфредо Парето, наголошуючи:

Хто впроваджує в світ і здійснює якусь ідею? Провансальці, демократи і прочі народолюбці відповідали - завше народ! Ми відповідаємо ніколи народ! Народ є для всякої ідеї, чи в її статичному, чи в динамічному стані - чинник пасивний, той що приймає. Чинником активним, тим, що несе ідею, тим, де ця ідея зроджується є - активна, або ініціативна меншість. Називають їі різно: «класово свідомий пролетаріат» (в противність до переважаючої маси «несвідомого»), «національно свідома інтелігенція», «аристократія», «правляча кліка», «тирани». [...] але - суть цієї меншости та ̈̈ роля в усіх громадських одиницях та сама. Це група, яка формує, неясну для «неусвідомленої» маси, ідею, робить їі приступною цій масі i, нарешті, мобілізує «народ» для боротьби за цю ідею. ${ }^{116}$

У праці Дух нашої давнини, наприклад, Донцов використовує термін «каста», а саме:

Нова каста нових людей, з новою думкою, з новими організаційними ідеалами [...] Активна верства, що об'єднає націю, вийде не з вибору, а 3 добору [...] Створити цю нову касту - завдання нашого часу ${ }^{117}$.

Іван Франко наполягає на ключовій ролі інтелігенції у розбудові суспільства і творенні майбутнього, оскільки вважає інтелігенцію найбільш свідомою та прогресивною верствою серед усіх інших, вона завжди має бути попереду, але не демонструючи власної вищості ${ }^{118}$. Франко підкреслює, що «всесвітня історія - не історія героїв, а історія масових рухів і перемін; а ми ж кожний особисто хіба не часть тої маси, яка сими подіями покликана до руху та перемін?» ${ }^{119}$. Цікаво,

115 Див.: там само. - С. 108.

116 Донцов Д. Творче насилля та ініціативна меншість як порядкуючи сили шоста вимога волевого націоналізму // Дві концепції української політичної думки Вячеслав Липинський - Дмитро Донцов / упоряд. Г. Васькович. - Нью Йорк, 1990. - С. 194-195.

117 Донцов Д. Дух нашої давнини. - Мюнхен - Монреаль, 1951. - С. 7-8.

118 Франко І.Я. Поза межами можливого. Що таке поступ? Одвертий лист до галицької молодежі. - Київ : ПрАТ Українська Прес-група, 2012. - С. 73.

119 Див.: там само. - С. 68. 
що письменник також звертається до теми розрізненості української політичної еліти і стверджує, що це є головною перепоною для історичного розвитку українського народу, що має бути подолана. Він пише: «не сміємо своїх дрібних, локальних справ виставляти як справи всенародні, своїх дрібних персональних амбіцій висувати на першу лінію загального інтересу» ${ }^{120}$.

Автори теорій нового постіндустріального суспільства - Деніел Белл, Джон Гелбрейт, Елвін Тоффлер, спостерігаючи й аналізуючи бурхливий розвиток науки і технологій у сучасному світі, пов'язують прогресивний історичний поступ людства з діяльністю, перш за все, наукової та науково-технічної інтелігениій. Наприклад, Белл у праці Майбутне постіндустріальне суспільство на питання: «хто буде керувати?», дає досить пряму відповідь - технічна інтелігенція (вчені).

У постіндустріальному суспільстві технічні знання стають основою, а освіта - засобом досягнення влади; ті (елітна частина суспільства), хто висувається на перший план, представлені дослідниками і вченими. Але це не означає, що вчені монолітні і діють як корпоративна група. У практичних політичних ситуаціях вони можуть розходитися ідеологічно [...] і різні групи вчених можуть об'єднуватися з різноманітними частинами інших еліт. [...] При зміні системи у постіндустріальному суспільстві стають очевидними дві обставини: по-перше, вчені як окрема страта, або, у більш широкому плані, технічна інтелігенція, тепер повинні братися до уваги в політичному процесі, чого не відбувалося ніколи раніше; по-друге, сама по собі наука керується етосом, що відрізняється від етоса інших основних соціальних груп (наприклад, підприємців та військових), і цей етос обумовлює відмінну від інших груп поведінку вчених у політичному плані. ${ }^{121}$

Гелбрейт, розмірковуючи про «нове індустріальне суспільство», вводить спеціальний термін для позначення тих, хто буде визначати напрямок його розвитку - «техноструктура» (або «розвинута корпорація»). Під останньою він розуміє групу людей, які приймають участь у прийнятті рішень на підприємстві чи в організації, являють собою $\dddot{1}$ мозок. Гелбрейт підкреслює, що це не адміністрація підприємства (чи організації), а невелика група людей, котра працює над інформацією, яка, у свою чергу, використовується для прийняття групового рішення на користь організації 122 .

120 Див.: там само. - С. 73.

${ }^{121}$ Белл Д. Грядущее постиндустриальное общество. Опыт социального прогнозирования. - Москва: Academia, 2004. - С. 481-483.

122 Гелбрейт Дж.К. Новое индустриальное общество. Избранное. - Москва: Эксмо, 2008. - С. 84. 
Гелбрейт зазначає, що для західної цивілізації особистість як дієвець історії є більш прийнятною, аніж група. Ми з повагою і симпатією ставимося до особистості, яка намагається уникнути поглинання натовпом. Однак, на сьогодні ситуація є такою, що і на підприємстві й у суспільстві влада перейшла від окремих особистостей до організацій, тому що організації мають певні переваги над особистістю з точки зору рішення важливих суспільних завдань.

Необхідність такої групової індивідуальності обумовлюється вже тією обставиною, що у сучасній промисловості значну кількість рішень - і усі істотно важливі рішення - приймаються на основі інформації, котрою володіє не одна людина, а велика кількість людей. Як правило, ці рішення засновуються на спеціальних наукових і технічних знаннях, на накопиченій інформації і досвіді, на професійному чутті або інтуїції великої кількості осіб. ${ }^{123}$

Тоффлер у праці «Третя хвиля» говорить про технореволюціонерів (або «агентів третьої хвилі») як про ключового дієвця історії у суперіндустріальну добу. Тоффлер структурує усю історію людства у три періоди: аграрне суспільство, індустріальне суспільство та суперіндустріальне суспільство. В основі такого поділу покладено розвиток науки і виробництва, а оскільки розвиток науки й знання відбувається, на думку Тоффлера, ривками (результати яких людство опрацьовує ще певний період часу), він пропонуе називає їх «хвилями» (маються на увазі хвилі глобальних соціокультурних та технологічних змін). Цивілізація «третьої хвилі» лише народжуеться, вона настільки глибоко революційна, що «кидає виклик усім нашим старим вихідним настановам. Старі способи мислення, старі формули, догми та ідеології, незважаючи на те, що у минулому вони процвітали або були досить корисними, вже не відповідають більше фактам. Світ, який виникає з надзвичайною швидкістю із зіткнення нових цінностей і технологій, нових геополітичних відносин, нових стилів життя і способів комунікації, потребує абсолютно інших ідей та аналогій, класифікацій і понять. Ми не можемо втиснути ембріональний завтрашній світ у прийняті учора категорії. Ортодоксальні соціальні настанови чи настрої теж не підходять цьому новому світові» 124 .

До складу технореволюціонерів Тоффлер відносить людей, що мають глибоку наукову підготовку - фізики, фізики-ядерники, генетики, біохіміки, медики. І рунтуючись на нових технологіях, зосереджених

123 Див.: там само. - С. 75.

${ }^{124}$ Toffler A. The Third Wave. - New York: William Morrow and Company, 1980. P. 18-19. 
у чотирьох промислових кластерах - електроніка і комп'ютери, космічна промисловість, дослідження морів та океанів, генна індустрія, технореволюціонери прагнутимуть подолати старі принципі виробництва індустріальної епохи. До своєрідної програми промислових перетворень, що охоплять собою усі сфери життя людини, можна віднести еко-спрямованість виробництва; технології, спрямовані на покращення умов життя і праці (від виробництва їжі до виробництва енергії $з$ концентрацією на потребах локального ринку, а не державного чи світового); смарт-технології, які не мають бути громіздкими, дорогими чи надто складними, щоб бути «розумними»; відмову від ресурсовиснажуючих і забруднюючих природне середовище технологій ${ }^{125}$.

Анрі Турен пропонує розглядати у якості основного «агента еволюцї» суспільні рухи (соціокультурні, суспільно-історичні, суспільні рухи у строгому сенсі слова), хоча наголошує, що в їхній основі він вбачає «повернення людини діяльної» ${ }^{126}$. Суспільний рух являє собою одночасно культурно-орієнтовану і соціально конфліктну дію певного суспільного класу, котрий визначається позицією панування або залежності у процесі привласнення історичності, тобто тих культурних моделей інвестиціі, знання й моралі, на які він сам зорієнтований ${ }^{127}$. Відповідно до думки Турена, постіндустріальне суспільство має тенденцію бути масовим, воно здійснює усе більш масштабну «мобілізацію» населення. У такій ситуації влада стає більш чутливою і залежною від «суспільної думки», а роль інтелігенції послаблюється. Під інтелігенцією розуміється сукупність освічених людей, що являють собою посередників між політичною системою та верствами населення, виключеними з неї. За таких умов у суспільстві ми спостерігаємо боротьбу різних груп впливу й інтересів ${ }^{128}$.

Суспільна думка може лишатися байдужою, коли націоналізують підприємства або навіть збільшують права профспілок. Але коли змінюють статус телебачення, обговорюють права жінок (наприклад, переваги та негативні сторони контрацепції), коли торкаються проблем евтаназії або перспективи генетичних маніпуляцій, кожен відчуває себе особисто і колективно зацікавленим. Повернувся час емоцій, як у психологічному, так і у старому історичному значенні цього слова. ${ }^{129}$

Сучасні суспільні рухи чітко відрізняються своєю ціннісною спрямова-

125 Див.: там само. - Р. 166, 156-164, 167-169.

${ }^{126}$ Турен А. Возвращение человека действующего. Очерк социологии. - Москва : Научный мир, 1998. - С. 92, 29.

127 Див.: там само. - С. 89.

128 Див.: там само. - С. 147.

129 Див.: там само. - С. 30. 
ністю, тобто вони більш прямо ставлять під питання цінності культури і суспільства. Тому вони засновуються не лише на соціальних, але й на інтелектуальних та етичних переконаннях, а також найкраще проявляються у болісних коливаннях між минулим (старі ідеології) і майбутнім (нові ідеї й цінності, що надають сили для супротиву і змін) ${ }^{130}$, що найбільш яскраво зараз демонструють масові ати-расистські та антидискримінаційні акції протесту у Сполучених Штатах Америки, Великобританії, Франції, Бельгії.

Таким чином, можна зробити наступні висновки: по-перше, вводиться нове поняття «дієвець історіі» для позначення людини або групи, або великої спільноти, яка своїми діями чи бездіяльністю у минулому безпосередньо творить історію; по-друге, введення нового поняття конкретизує предмет дослідження і дозволяє уникнути термінологічної плутанини, пов'язаної з використанням традиційного поняття «суб'єкт історії», яким у однаковій мірі позначають як дієвця історії, так і історика, а також надає гідну альтернативу використанню поняття «творець історії», що має певні релігійні конотації (Бог як творець світу та історії); по-трете, питання ключового дієвця в історії є досить широким, включає в себе багато аспектів і точок зору. Це може бути видатна історична особистість (політик, релігійний пророк, герой, поет або митець), соціальна група (соціальний клас, правляча еліта, аристократія, творча меншість, технічна інтелігенція, соціальний рух) та великі колективні спільноти (народ, нація, раса, маси, людство загалом). Усі вищерозглянуті концепції єднає спільна думка, що минуле $є$ результатом системної активності багатьох історичних дієвців, однак домінуюча прогресивна роль, як правило, віддається лише одному 3 них.

\section{References}

[1] Anderson B. Voobrazhaemye soobshestva. Razmyshleniya ob istokah i rasprostranenii nacionalizma. - M. : KANON-press-C, Kuchkovo pole, 2001.

[2] Bell D. Gryadushee postindustrialnoe obshestvo. Opyt socialnogo prognozirovaniya. - M. : Academia, 2004.

[3] Bromlej Yu.V. Ocherki teorii etnosa. - M. : Nauka, 1983.

130 Див.: там само. - С. 169-170. 
[4] Buden B. Zona perehodu. Pro kinecz postkomunizmu. - K.: Meduza, 2013.

[5] Veber M. Hozyajstvo i obshestvo: ocherki ponimayushej sociologii v 4 t. - T. 1. - M. : Izd. dom Vysshej shkoly ekonomiki, 2016.

[6] Voropayeva T. Rol osobystosti v ukrayinskij istoriyi kriz pryzmu biografistyky // Ukrayinska biografistyka. - 2016. - № 14. - S. 50-70.

[7] Gegel G.V.F. Lekcii po filosofii istorii. - SPb. : Nauka, 1993.

[8] Gelbrejt Dzh.K. Novoe industrialnoe obshestvo. Izbrannoe. - M.: Eksmo, 2008.

[9] Gellner E. Naciyi ta nacionalizm. Nacionalizm. - K. : Takson, 2003.

[10] Gerder I.G. Idei k filosofii istorii chelovechestva. - M. : Nauka, 1977.

[11] Gobino Zh.A. de. Opyt o neravenstve chelovecheskih ras. - M.: OLMA-PRESS, 2000.

[12] Gumilev L.N. Etnosfera: Istoriya lyudej i istoriya prirody. - M.: Ekopros, 1993.

[13] Danilevskij N.Ya. Rossiya i Evropa. - M. : Kniga, 1991.

[14] Darendorf R. Elementy teorii socialnogo konflikta // Sociologicheskie issledovaniya. - 1994. - № 5. - S. 142-147.

[15] Dojchyk M.V. Filosofiya istoriyi : navchalno-metodychnyj posibnyk. Ivano-Frankivsk: Symfoniya forte, 2010.

[16] Donczov D. Nacionalizm. - Lviv: Vydavnycztvo Nove zhyttya, 1926.

[17] Donczov D. Tvorche nasyllya ta iniciatyvna menshist yak poryadkuyuchy syly - shosta vymoga volevogo nacionalizmu // Dvi koncepciyi ukrayinskoyi politychnoyi dumky Vyacheslav Lypynskyj Dmytro Donczov / uporyad. G. Vaskovych. - Nyu Jork, 1990.

[18] Lypynskyj $V$. Lysty do brativ-hliborobiv. Pro ideyu i organizaciyu ukrayinskogo monarhizmu // Lypynskyj V. Povne zibrannya tvoriv, arhiviv, studij : u 25 t. - T.6., Kn. 1. - Kyyiv - Filadelfiya: Instytut Shidnoyevropejskyh doslidzhen NANU; Shidnoyevropejskyj doslidnyj instytut, 1995. 
[19] Yevtuh V.B. Etnichnist: encyklopedychnyj dovidnyk. - K.: Feniks, 2012.

[20] Karsavin L.P. Filosofiya istorii. - SPb. : AO KOMPLEKT, 1993.

[21] Kasyanov G. Past continuous: istorychna polityka 1980-h - 2000-h. Ukrayina ta susidy. - K. : Laurus, Antropos-Logos-Film, 2018.

[22] Kolodij A. Oznaky naciyi yak modernoyi sociokulturnoyi i politychnoyi spilnoty [Elektronnyj resurs] / Avtorskyj sajt Antoniny Kolodij. - Rezhym dostupu: https://political-studies.com/?page_id $=344$

[23] Lebon G. Psihologiya tolp // Psihologiya tolp. - M. : Institut psihologii RAN, Izdatelstvo KSP +, 1998.

[24] Lypynskyj V. Poklykannya «varyagiv», chy organizaciya hliborobiv? - Nyu Jork: Vydavnycha Korporaciya Bulava, 1954.

[25] Lokk Dzh. Dva traktaty pro vryaduvannya. - K.: Vydavnycztvo Solomiyi Pavlychko OSNOVY, 2001.

[26] Makiavelli N. Gosudar // Makiavelli N. Izbrannye sochineniya. - M. : Hudozh. Lit., 1982.

[27] Marks K., Engels F. Manifest Komunistychnoyi partiyi // Kyrylyuk F.M. Istoriya zarubizhnyh politychnyh vchen Novoyi doby: [navch. posib.]. - K.: Centr uchbovoyi literatury, 2008. - S. 310-312.

[28] Marks K., Engels F. Nemeckaya ideologiya. - M. : Politizdat, 1988.

[29] Mishalova O.V. Ideya progresu ta modeli rozgortannya istorychnogo procesu // Aktualni problemy duhovnosti: zb. nauk. pracz. - Kryvyj Rig: KDPU, 2018. - Vyp. 19. - S. 175-180.

[30] Mizes L. Teoriya i istoriya: Interpretaciya socialno-ekonomicheskoj evolyucii. - M. : YuNITI-DANA, 2001.

[31] Nicshe F. Po tu storonu dobra i zla // Nicshe F. Sochineniya: v 2-h tomah. - M. : Mysl, 1990. - T. 2.

[32] Ortega-i-Gasset H. Vosstanie mass. - M.: OOO Izdatelstvo AST, 2002. 
[33] Pavlenko Yu. Istoriya svitovoyi cyvilizaciyi: sociokulturnyj rozvytok lyudstva: navchalnyj posibnyk. - K. : Lybid, 2000.

[34] Pareto V. Kompendium po obshej sociologii. - M. : Izdatelskij dom GU VShE, 2008.

[35] Predborska I.M., Ganaba S.O. Filosofiya istoriyi: navchalnyj posibnyk. - Sumy: Universytetska knyga, 2012.

[36] Radej A.S. Etnos i naciya. Analiz definicij // Multyversum. Filosofskyj almanah. - 2015. - Vyp. 1-2 (139-140). - S. 67-76.

[37] Svetonij Trankvill Gaj. Zhizneopisanie dvenadcati cezarej. - M. - L. : ACADEMIA, 1933.

[38] Smit E.D. Nacionalna identychnist. - K. : Osnovy, 1994.

[39] Tojnbi A. Doslidzhennya istoriyi : u 2 t. - T. 1. - K. : Osnovy, 1995.

[40] Turen A. Vozvrashchenie cheloveka dejstvuyushchego. Ocherk sociologii. - M. : Nauchnyj mir, 1998.

[41] Filosofiya istoriyi : pidruchnyk / I.V. Bojchenko [ta in.] - Harkiv: Prapor, 2006.

[42] Franko I.Ya. Poza mezhamy mozhlyvogo. Shho take postup? Odvertyj lyst do galyczkoyi molodezhi. - K. : PrAT Ukrayinska Pres-grupa, 2012.

[43] Fromm E. Begstvo ot svobody. - M. : Izdatelstvo AST, 2018.

[44] Yashhuk T.I. Filosofiya istoriyi: Kurs lekciyi : navchalnyj posibnyk. K. : Lybid, 2004.

[45] Arendt H. The Origins of Totalitarianism. - San Diego-New YorkLondon: A Harvest Book: Harcourt Brace and Company, 1976.

[46] Carlyle T. On Heroes, Hero-Worship, and the Heroic in History. New Haven and London: Yale University Press, 2013.

[47] Gellner E. Selected Philosophical Themes. Volume II. Contemporary Thought and Politics. - London and New York: Routledge: Taylor and Francis Group, 2003. 
[48] Huntington S.P. The Clash of Civilization and the Remaking of World Order. - New York: Simon and Schuster, 1996.

[49] Marcuse H. One-Dimensional Man. Studies in the ideology of advanced industrial society. - London and New York: Routledge Classics, 2002.

[50] Michels R. Political Parties: A Sociological Study of the Oligarchical Tendencies of Modern Democracy. - New Brunswick (USA) and London (U.K.) : Transaction Publishers, 1999.

[51] Mosca G. The Ruling Class. - New York and London: McGraw-Hill Book Company, 1939.

[52] Toffler A. The Third Wave. - New York: William Morrow and Company, 1980.

Надійшла до редакиї 07 серпня 2020 р. 


\section{Мішалова Олена Віталіївна}

(1) Кафедра філософії, Школа публічного адміністрування Нанкінський класичний університет

Нанкін, КНP

210000

(2) Кафедра філософії

Криворізький державний педагогічний університет

Просп. Гагаріна, 54

Кривий Ріг, Україна

50086

\section{Mishalova Olena}

(1) Department of Philosophy, School of Public Administration Nanjing Normal University

Nanjing, China, 210000

(2) Department of Philosophy

Kryvyi Rih State Pedagogical University

Gagarina ave., 54

Kryvyi Rih

50086

(iD https://orcid.org/0000-0001-5469-6451

@ elenmishalova@gmail.com

doi $10.31812 /$ apd.v0i21.3877 